\title{
Mezinárodní konsenzus European Heart Rhythm Association (EHRA) o tom, jak předcházet infekcím implantabilních elektronických srdečních zařizení, diagnostikovat a léčit je.
}

\author{
Souhrn dokumentu připravený Českou kardiologickou společností
}

(European Heart Rhythm Association (EHRA) international consensus document on how to prevent, diagnose, and treat cardiac implantable electronic device infections. Summary of the document prepared by the Czech Society of Cardiology)

\author{
Miloš Táborskýa, Josef Kautzner ${ }^{b}$, Petr Neužilc, Marián Fedorco , Hanka \\ Wünschováb, Lucie Šedivác, Jan Pyszko a, Tomáš Skálaa, Jan Látala, Miroslav

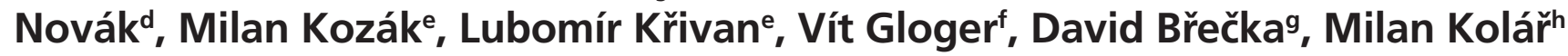 \\ a I. interní klinika - kardiologická, Lékařská fakulta Univerzity Palackého a Fakultní nemocnice Olomouc \\ ${ }^{b}$ Klinika kardiologie, Institut klinické a experimentální medicíny, Praha \\ ' Kardiovaskulární centrum, Nemocnice Na Homolce, Praha \\ ¿ l. interní kardioangiologická klinika, Lékařská fakulta Masarykovy univerzity a Fakultní nemocnice u sv. Anny v Brně \\ e I. interní klinika, Lékařská fakulta Masarykovy univerzity a Fakultní nemocnice Brno \\ ${ }^{f}$ Kardiologické oddělení, Krajská nemocnice Tomáše Bati, Zlín \\ ${ }^{g}$ Kardiologické oddělení, Fakultní nemocnice Ostrava \\ h Ústav mikrobiologie, Lékařská fakulta Univerzity Palackého a Fakultní nemocnice Olomouc
}

Autoři originálního textu EHRA:1 Carina Blomström-Lundqvist, Vassil Traykov.

\section{INFORMACE O ČLÁNKU}

Historie článku:

Vložen do systému: 5. 6. 2020

Prijat: 6. 6. 2020

Dostupný online: 18. 6. 2020

\section{Kličová slova:}

Elektrody

Endokarditida

Extrakce

Implantabilní elektronická zařizení

Implantabilní

kardiovertery-defibrilátory

Infekce

Konsenzuální dokument EHRA

Mikrobiologie

Reimplantace

Srdeční kardiostimulátory

Srdeční resynchronizační léčba

\section{Keywords:}

Cardiac implantable electronic devices Cardiac resynchronization therapy EHRA consensus document Endocarditis

\section{SOUHRN}

Kardiostimulátory, implantabilní kardiovertery-defibrilátory a přístroje pro srdeční resynchronizační terapii jsou potenciálně život zachraňujíci léčbou u řady srdečních onemocnění, ale nejsou bez rizika. Nejvíce znepokojující je riziko infekce srdečních implantabilních elektronických zařízení (CIED), která je spojena s významnou morbiditou, zvýšenou nutností hospitalizace, zkrácením přežití a zvýšenými náklady na zdravotní péči. Doporučené preventivní postupy, jako je podávání intravenózních antibiotik před implantací, jsou dobře známy. Zưstávají nejasnosti ohledně úlohy různých preventivních, diagnostických a léčebných opatření, jako jsou kožní antiseptika, aplikace antibiotik do kapsy př́stroje, antibakteriální obálky, prodloužené podávání antibiotik po implantaci a další. Doporučení týkající se použití nových alternativ implantabilních zařízení, u nichž se očekává, že budou méně náchylné $\mathrm{k}$ infekcím, a nových perorálních antikoagulancií jsou rovněž omezená, stejně jako definice minimálních požadavků na kvalitu péče implantačních center, erudice operatérů a počtu výkonů. Navíc chybí dokument o mezinárodním konsenzu ohledně léčby infekcí CIED. Rozpoznání těchto témat, šiření výsledků dủležitých randomizovaných studií zaměřených na prevenci infekce CIED a pozorované rozdíly v řešení infekcí souvisejících s implantabilními přistroji, které byly zjištěny v celosvětovém průzkumu European Heart Rhythm Association, poskytlo silnou motivaci $k$ vytvoření mezinárodního konsenzuálního dokumentu s použitím nejmodernějších poznatků vědy z roku 2019 týkajících se posuzování rizik, prevence, diagnostiky a léčby infekcí CIED.

(C) The Author(s) 2019. Published by Oxford University Press on behalf of the European Society of Cardiology.

\section{ABSTRACT}

Pacemakers, implantable cardiac defibrillators, and cardiac resynchronization therapy devices are potentially life-saving treatments for a number of cardiac conditions, but are not without risk. Most concerning is the risk of a cardiac implantable electronic device (CIED) infection, which is associated with significant morbidity, increased hospitalizations, reduced survival, and increased healthcare costs. Recommended preventive strategies such as administration of intravenous antibiotics before implantation are well recognized. Uncertainties have remained about the 
role of various preventive, diagnostic, and treatment measures such as skin antiseptics, pocket antibiotic solutions, anti-bacterial envelopes, prolonged antibiotics post-implantation, and others. Guidance on whether to use novel device alternatives expected to be less prone to infections and novel oral anticoagulants is also limited, as are definitions on minimum quality requirements for centres and operators and volumes. Moreover, an international consensus document on management of CIED infections is lacking. The recognition of these issues, the dissemination of results from important randomized trials focusing on prevention of CIED infections, and observed divergences in managing device-related infections as found in an European Heart Rhythm Association worldwide survey, provided a strong incentive for a 2019 International State-of-the-art Consensus document on risk assessment, prevention, diagnosis, and treatment of CIED infections.
Extraction

Implantable cardioverter-defibrillators Infection

Leads

Microbiology

Pacemakers

Re-implantation

\section{Úvod}

\section{Rozsah konsenzuálního dokumentu}

Kardiostimulátory (KS), implantabilní kardiovertery-defibrilátory (ICD) a přístroje pro srdeční resynchronizační léčbu (cardiac resynchronization therapy, CRT) jsou život zachraňující léčbou řady srdečních onemocnění. Infekce související s těmito přístroji je však jednou z nejzávažnějších komplikací léčby srdečními implantabilními elektronickými zařízeními (cardiac implantable electronic device, CIED) a je spojena s významnou morbiditou, mortalitou a finanční zátěží pro zdravotnictví. Přestože je dobře známo mnoho preventivních postupů, jako je podávání intravenózní (i.v.) antibiotické terapie před implantací, stále existují nejasnosti ohledně jiných opatření. Nadále přetrvávají otázky, jako je použití alternativ CIED, u nichž se očekává, že budou méně náchylné $\mathrm{k}$ infekcím, jak upravit farmakologickou léčbu, jako jsou antikoagulancia během implantace přistrojů, a také otázka minimálních požadavků na kvalitu a počet výkonů pro jednotlivá centra a operatéry. Rozpoznání těchto mezer ve znalostech, zprávy o nových důležitých randomizovaných studiích, pozorované rozdíly v léčbě infekcí souvisejících se zařízeními a nedostatek dokumentů $s$ mezinárodním konsenzem, které se konkrétně zaměřují na infekce CIED, poskytly silnou motivaci pro vytvoření mezinárodního konsenzuálního dokumentu s použitím nejmodernějších poznatků vědy z roku 2019 týkajících se posuzování rizik, prevence, diagnostiky a léčby infekcí CIED. Cílem tohoto dokumentu je popsat současné znalosti o rizicích infekcí spojených $s$ prístroji a pomoci zdravotnickým pracovníkủm při jejich klinickém rozhodování v jejich prevenci, diagnostice a léčbě pomocí aktuálně nejúčinnějších postupů.

\section{Metodika}

Tento konsenzuální dokument je výsledkem spolupráce sedmi odborných společností a asociací, European Heart Rhythm Association (EHRA), Heart Rhythm Society (HRS), Asia Pacific Heart Rhythm Society (APHRS), Latin American Heart Rhythm Society (LAHRS), European Association for Cardio-Thoracic Surgery (EACTS), European Society of Clinical Microbiology and Infectious Diseases (ESCMID) a International Society for Cardiovascular Infectious Diseases (ISCVID). Soubor autorů, který se skládal ze 16 členů pracovní skupiny, byl vybrán na základě jejich odborných znalostí a lékařské specializace (12 kardiologů s různou specializací, dva specialisté na infekční choroby, jeden specialista na zobrazovací metody a jeden hrudní chirurg), z 11 zemí na čtyřech kontinentech. Všichni odborníci prováděli podrobné komplexní rešerše literatury publikované do května 2019 (výzkum publikovaný v angličtině a indexovaný v hlavních databázích, jako jsou MEDLINE, EMBASE, Cochrane Library a další podle potřeby) týkající se studované kohorty pacientů a tématu infekcí CIED za použití relevantních hledaných pojmů odkazujících na studované téma a předchozí doporučené postupy. Byly provedeny systematické revize publikovaných důkazů pro řešení daných stavů a klinických problémů. Členové byli požádáni, aby zvážili sílu důkazů pro konkrétní diagnostický nástroj a proti němu, postup nebo léčbu a zahrnuli odhady očekávaných zdravotních výsledků a posoudili poměr rizika a prospěšnosti tam, kde existují data.

Byly zváženy modifikující faktory specifické pro pacienty, zařízení a postupy, stejně jako výsledky mezinárodního průzkumu infekcí CIED prováděného za tímto účelem a předchozích registrů. Konsenzuální stanoviska byla založena na důkazech, odvozena primárně z publikovaných dat a na základě důkladného zvážení, vyža-

Tabulka 1 - Vědecké odůvodnění doporučeni

\begin{tabular}{|c|c|c|c|}
\hline $\begin{array}{l}\text { Konsenzuální stanovisko } \\
\text { týkající se léčby } \\
\text { nebo postupu }\end{array}$ & Definice stanoviska & $\begin{array}{c}\text { Trída } \\
\text { stanoviska }\end{array}$ & $\begin{array}{l}\text { Kódování } \\
\text { vědecké } \\
\text { evidence (SEC) }\end{array}$ \\
\hline $\begin{array}{l}\text { Doporučeno/indikováno nebo } \\
\text { „mělo by se dělat' }\end{array}$ & $\begin{array}{l}\text { Vědecký důkaz, že léčba nebo postup je přínosný a účinný; vyžaduje } \\
\text { alespoň jednu randomizovanou studii nebo je podporován velkými } \\
\text { observačními studiemi a souhlasem autorů }\end{array}$ & & $\mathrm{R}$ \\
\hline $\begin{array}{l}\text { Může být použito nebo } \\
\text { doporučeno }\end{array}$ & $\begin{array}{l}\text { Obecná shoda a/nebo vědecké důkazy upřednostňují užitečnost/ } \\
\text { účinnost léčby nebo postupu; múže být podporována } \\
\text { randomizovanými studiemi založenými na malém počtu pacientů } \\
\text { nebo nejsou široce použitelné }\end{array}$ & & 0 \\
\hline $\begin{array}{l}\text { Nemělo by být použito nebo } \\
\text { doporučeno }\end{array}$ & $\begin{array}{l}\text { Vědecké důkazy nebo obecná shoda nepoužívat nebo nedoporučit } \\
\text { léčbu nebo postup }\end{array}$ & & $E$ \\
\hline
\end{tabular}

Tato kategorizace pro konsenzuální dokument by neměla být považována za shodnou s tou, která byla použita pro oficiální doporučené postupy, které uplatňují klasifikaci (I-III) a úroveň důkazů ( $A$, B a C). Kódování „ROME“ bylo použito na každé konsenzuální prohlášení a definuje stávající vědecké důkazy. $\mathrm{E}$ - odborné stanovisko; $\mathrm{M}$ - metaanalýzy; O - observační studie; $\mathrm{R}$ - randomizovaná studie. 
Tabulka 2 - Patogeny izolované u pacientů podstupujících výkony pro infekci přístroje ze tři velkých kohort pacientů

v Severní Americe, Evropě a Asii

\begin{tabular}{|c|c|c|c|}
\hline \multirow{2}{*}{ Patogen } & \multicolumn{3}{|c|}{ Procento izolátů } \\
\hline & Severní Amerika & Evropa & Asie \\
\hline Koaguláza-negativní stafylokok & & 69 & 45,2 \\
\hline Methicilin-rezistentní & 18,8 & & \\
\hline Methicilin-senzitivní & 18,8 & & \\
\hline Staphylococcus aureus & & 13,8 & 4,1 \\
\hline Methicilin-senzitivní & 15,8 & & \\
\hline Methicilin-rezistentní & 15,0 & & \\
\hline Streptococcus spp. & 2,5 & & \\
\hline \multicolumn{4}{|l|}{ Enterococcus spp. } \\
\hline Vancomycin-senzitivní & 2,8 & & \\
\hline Vancomycin-rezistentní & 1,4 & & \\
\hline Cutibacterium spp. (dř́ve Propionibacterium spp.) & & 2,5 & \\
\hline Corynebacterium spp. & & 5 & \\
\hline Gram-negativní bakterie & 8,9 & 6,1 & 9,1 \\
\hline Enterobakterie & & 3 & 3,2 \\
\hline Nefermentující bacily včetně Pseudomonas spp. & & 1,5 & 5,9 \\
\hline Anaeroby & 1,6 & & \\
\hline Plísně & 0,9 & 1 & 0,9 \\
\hline Mykobakterie & 0,2 & & \\
\hline
\end{tabular}

dující alespoň 80 \% předdefinovaných souhlasů doručených e-mailem od předsedů všem členům k získání jejich souhlasu nebo odmítnutí. Pro rozlišení úrovně vědeckých důkazů byl v dokumentu použit uživatelsky přátelský systém hodnocení konsenzuálních dokumentů EHRA s „barevnými srdíčky” popisující aktuální stav důkazů a z toho plynoucí další poučení (tabulka 1). Hodnocení nemá rozdělené stupně podle síly důkazů, ty jsou vždy zahrnuty u jednotlivých barevných srdcí pomocí kódování písmeny „ROME“, R pro randomizované studie, O pro observační studie, M pro metaanalýzy a E pro odborné stanovisko (expert opinion) (tabulka 1). Dokument byl posouzen oficiálními externími recenzenty zastupujícími EHRA, dalšími zúčastněnými společnostmi a Committee for Practice Guidelines (CPG) Evropské kardiologické společnosti (ESC). Na konci tohoto dokumentu zveřejnili všichni členové autorské skupiny i recenzenti potenciální střety zájmů. Vzhledem k tomu, že tento konsenzuální dokument zahrnuje data a odborná stanoviska z různých zemí a zdravotnických systémů, zmíněné lékařské přístupy mohou zahrnovat léky nebo prístroje, které nejsou schváleny regulačními agenturami vlád jednotlivých zemí. Navíc konečné rozhodnutí o postupu musí učinit poskytovatel zdravotní péče a pacient na základě posouzení individuálních faktorů.

\section{Pozadí a epidemiologie}

V posledních desetiletích došlo k podstatnému nárůstu v počtu a složitosti implantací CIED v důsledku rozšíření indikací a postupného stárnutí populace. Přestože tato zařízení zlepšují kardiovaskulární přežívání, vystavují také pacienty riziku možných komplikací.
Infekce je jednou z nejzávažnějších komplikací léčby CIED a je spojena s významnou mortalitou, morbiditou a finanční zátěží zdravotnického systému. Je obtížné stanovit přesnou míru výskytu infekcí CIED vzhledem k rozdílným definicím, rưzným populacím a rozsahu hodnot v retrospektivních a prospektivních studiích. $V$ Dánském registru zahrnujícím 46299 pacientů, kteří podstoupili implantaci kardiostimulátoru v letech 1982 až 2007, byl výskyt infekce 4,82/1 000 zařízení a let po primoimplantaci a 12,12/1 000 zařízení a let po výměně. Greenspon a spol. zjistili, že výskyt infekce CIED ve Spojených státech amerických vzrostl z 1,53 \% v roce 2004 na 2,41\% $\checkmark$ roce 2008 a National Inpatient Sample database study ukázala vzestup z 1,45 \% na 3,41\% $(p<0,001)$ od roku 2000 do roku 2012, zejména u prístrojů pro CRT. Výskyt infekce v prospektivních observačních studiích, registrech a novější zkřížené shlukové studii PADIT a randomizované studii WRAP-IT byl jen 0,6-1,3\% ve srovnání $s$ retrospektivními studiemi, které hlásily výrazně vyšší výskyt $(2,3-3,4 \%)$ v prvním roce po implantaci.

\section{Patogeneze a pưvodci infekcí srdečních implantabilních elektronických zařízení}

K infekci spojené se srdečními implantabilními přístroji dochází dvěma hlavními mechanismy. Nejběžnější je kontaminace elektrod a/nebo samotného přístroje během implantace nebo následné manipulace. Eroze zařízení později po výkonu může být bud' způsobena infekcí kapsy, nebo v ni vyústit. $V$ obou prípadech vede kontaminace a následná bakteriální kolonizace k infekci kapsy, která se může šírit podél intravaskulárních částí elektrod a zpưsobit systémovou infekci. Druhý mechanismus vzniku in- 
fekce je hematogenní. K osídlení elektrody může dojít během bakteriemie způsobené vzdálenými infekčními ložisky, jako jsou septická tromboflebitida, osteomyelitida, pneumonie, infekce v místě chirurgického zákroku, kontaminované cévní katétry nebo bakteriální vstup přes kůži, ústa, gastrointestinální nebo močový trakt.

Faktory, které hrají roli v patogenezi infekcí CIED, mohou souviset s hostitelem, zařízením nebo mikroorganismem. Vlastní kožní flóra pacienta může být zanesena do rány v okamžiku incize kưže, a tím kontaminovat zařízení. Kontaminace může také nastat před implantací vydechovaným vzduchem na operačním sále (hostitele i personálu) nebo rukou kohokoliv, kdo se zařízením manipuluje. Z patofyziologického hlediska jsou faktory související se zařízením ty, které ovlivňují bakteriální přilnavost $k$ prístroji nebo elektrodě a tvorbu biofilmu na těchto površích. Přilnavost bakterií usnadňují nepravidelné a hydrofobní povrchy. Z běžně používaných polymerů umožňuji polyvinylchlorid (PVC) a silikon lepší přilnavost než polytetrafluorethylen (PTFE), zatímco polyurethan umožňuje menší přilnavost než polyethylen. Kovy se také liší svou náchylností k adhezi bakterií, napríklad titan má menší sklon k osídlení bakteriemi než ocel. Normálně nepatogenní mikroorganismy, jako jsou koaguláza-negativní stafylokoky (CoNS), mohou adherovat k CIED a vytvořit ohnisko infekce. Nejčastěji izolované mikroorganismy byly grampozitivní bakterie (70-90 \%), zejména CoNS (37,6 \% izolátů) a Staphylococcus aureus (S. aureus, 30,8\%), které jsou mnohem náchylnější k adhezi na nebiologické materiály než ostatní (tabulka 2). Staphylococcus aureus je nejčastější příčinou bakteriemie a časných infekcí kapes. Celkem byly methicilin-rezistentní stafylokoky izolovány u 33,8 \% infekcí CIED (49,4 \% všech stafylokokových infekcí), jejich frekvence se lišila podle zemí, a dokonce i nemocnic. V posledních desetiletích se zdá, že míra rezistence na methicilin je vyšší než se dříve uváděla. Gramnegativní bakterie byly izolovány v 8,9 \%, zatímco jiní mikrobi, jako jsou streptokoky, anaeroby a houby, byli izolováni méně často (tabulka 2). Enterobakterie, další gramnegativní tyčinky a houby byly vzácné (tabulka 2).

\section{Rizikové faktory infekce srdečních implantabilních elektronických zařízení}

Rizikové faktory infekce CIED Ize rozdělit na faktory související s pacientem, výkonem a prístrojem. Tyto rizikové faktory mohou být (tabulka 1 a 2) dále děleny na modifikovatelné a nemodifikovatelné. Identifikace modifikovatelných rizikových faktorů je důležitá, protože může umožnit preventivní opatření ke snížení rizika. U pacientů s nemodifikovatelnými riziky mohou být alternativní postupy možností, jak snížit celkové riziko. Například hemodialýza je nemodifikovatelným rizikovým faktorem. Změnou postupu a/nebo zařízení a výběrem epikardiálního nebo subkutánního systému může být riziko sníženo. Několik studií prozkoumalo rozsáhlé databáze pro nejběžnější rizikové faktory. $V$ tabulce 3 je uvedena metaanalýza sdružených údajů zahrnujících 206176 pacientů v 60 studiích (z toho 21 prospektivních a 39 retrospektivních). Další velké studie, které analyzují rizikové faktory, zahrnují data z registru Medicare fee-for-service claims, studii National Inpatient Sample database s 85203 infekcemi, které souvisejí s implantabilními přístoji, a nedávnou Danish study s kohortou 97750 pacientů s implantovaným přístrojem. Souhrn nejdůležitějších rizikových faktorů označených $v$ těchto studiích je uveden v tabulce 3. Bohužel se význam rizikových faktorů $v$ jednotlivých studiích lišil a v některých prípadech byla zjištění protichůdná (jako napríklad věk).

Z faktorů souvisejících s pacientem bylo onemocnění ledvin a nutnost hemodialýzy konzistentně spojeno s nejvyšším rizikem, což podtrhuje důležitost pečlivého klinického vyšetření u těchto pacientů. Mezi rizikové faktory dle metaanalýzy patřily: nutnost pravidelné hemodialýzy, renální insuficience, diabetes mellitus, chronická obstrukční plicní nemoc, užívání kortikosteroidů, anamnéza předchozí infekce spojené s přístrojem, malignita, srdeční selhání, horečka před výkonem, užíaání antikoagulancií a kožní onemocnění, ale ne věk nebo pohlaví. $V$ kohortě Dánského registru však byl jako významné riziko identifikován mladší věk spolu s předchozí infekcí. Jiní označili jako silný rizikový faktor podvýživu (poměr šancí [OR] 2,44, $p<0,001$ ).

Pokud jde o faktory související s procedurou, antibiotická profylaxe byla spojena se $70 \%$ snížením relativního rizika infekce a je nyní standardem péče. Př́tomnost hematomu byla spojena s přibližně devítinásobně zvýšeným rizikem infekce. Tato zjištění byla později potvrzena prospektivní studií BRUISE CONTROL, která uváděla údaje od 659 pacientů, u nichž byl poměr rizik infekce 7,7 (95\% interval spolehlivosti [Cl]: 2,9-20,5; $p<0,0001)$ v prípadě klinicky významného hematomu (vyžadujícího chirurgický zákrok a/nebo vedoucího k prodloužené hospitalizaci > $24 \mathrm{~h}$ a/nebo vyžadujícího přerušení antikoagulace), přičemž až $11 \%$ z těchto pacientů mělo tuto komplikaci v průběhu jednoho roku sledování. Časná revize pro hematom nebo dislokaci elektrody byla identifikována jako nejsilnější rizikový faktor pro infekci CIED při srovnání dat z registrů přístrojů $s$ daty $z$ registru Medicare fee-for-service claims. Hematom byl také jedním z nejsilnějších rizikových faktorů (OR 2,66, $p<0,001)$ ve studii National Inpatient Sample database. Délka výkonu byla spojena s mnohonásobně zvýšeným rizikem infekce, ačkoli ve studiích byla významná heterogenita. Data z Dánského registru ukázala, že ve srovnání s postupy trvajícími méně než 30 minut bylo relativní riziko $(95 \% \mathrm{Cl})$ infekce u procedur trvajících 60-90, 90-120 nebo více než 120 minut 1,54 (1,24-1,91), $1,85(1,36-2,49), 2,42(1,77-3,33)$ v tomto pořadí. Stejný registr identifikoval implantaci prístroje CRT a reoperace jako vysoká a významná rizika. Další studie potvrdila časnou repozici elektrody jako silný prediktor infekce, ačkoli není dosud známo, zda by oddálení repozice riziko snížilo. Bylo také prokázáno, že použití dočasné stimulace (tabulka 3) zvyšuje riziko infekce (a nese riziko perforace/tamponády). To může být způsobeno odchylkami v míře sterility v důsledku nutnosti rychlého zavedení elektrody, potřebou její opakované manipulace a také jednoduše $v$ důsledku př́tomnosti dlouhodobého vstupu do krevního řečiště. Proto je třeba pečlivě zvážit indikaci pro dočasnou transvenózní stimulaci a promyslet také alternativní opatření, jako je záložní transtorakální 
Tabulka 3 - Souhrnné odhady účinku potenciálních rizikových faktorů predisponujících k infekci elektronických implantabilních zařízení

\begin{tabular}{|c|c|c|c|c|c|c|c|c|}
\hline \multirow[b]{2}{*}{ Faktor } & \multicolumn{4}{|c|}{ Prospektivní + retrospektivní studie } & \multicolumn{4}{|c|}{ Jen prospektivní studie } \\
\hline & $\begin{array}{l}\text { Studie } \\
\text { (n) }\end{array}$ & $\begin{array}{l}\text { Celkem } \\
\text { (n) }\end{array}$ & $\begin{array}{l}\text { Souhrnný } \\
\text { odhad }\end{array}$ & Hodnota $p$ & $\begin{array}{l}\text { Studie } \\
\text { (n) }\end{array}$ & $\begin{array}{l}\text { Celkem } \\
\text { (n) }\end{array}$ & $\begin{array}{l}\text { Souhrnný } \\
\text { odhad }\end{array}$ & Hodnota $p$ \\
\hline \multicolumn{9}{|l|}{ Faktory spojené s pacientem } \\
\hline $\begin{array}{l}\text { Terminální stadium selhání } \\
\text { ledvina }\end{array}$ & 8 & 3045 & $8,73(3,42,22,31)$ & 0,00001 & NA & & & \\
\hline Prodělaná infekce přístroje & 4 & 463 & $7,84(1,94,31,60)$ & 0,004 & NA & & & \\
\hline Horečka před výkonem & 3 & 6652 & $4,27(1,13,16,12)$ & 0,03 & 2 & 6580 & $5,34(1,002,28,43)$ & 0,05 \\
\hline Užívání kortikosteroidů & 10 & 3432 & $3,44(1,62,7,32)$ & 0,001 & 3 & 1349 & $2,10(0,47,9,32)$ & 0,33 \\
\hline Renální insuficience ${ }^{b}$ & 5 & 2033 & $3,02(1,38,6,64)$ & 0,006 & NA & & & \\
\hline CHOPN & 6 & 2810 & $2,95(1,78,4,90)$ & 0,00003 & 2 & 2393 & $2,30(0,97,5,48)$ & 0,06 \\
\hline NYHA II a více & 3 & 2447 & $2,47(1,24,4,91)$ & 0,01 & 2 & 2393 & $2,77(1,26,6,05)$ & 0,01 \\
\hline Kožní onemocnění & 4 & 6810 & $2,46(1,04,5,80)$ & 0,04 & 2 & 6519 & $2,60(0,88,7,70)$ & 0,08 \\
\hline Malignita & 6 & 1555 & $2,23(1,26,3,95)$ & 0,006 & NA & & & \\
\hline Diabetes mellitus & 18 & 11839 & $2,08(1,62,2,67)$ & $<0,000001$ & 7 & 9815 & $1,88(1,19,2,98)$ & 0,007 \\
\hline $\begin{array}{l}\text { Podávání heparinu před } \\
\text { výkonem - bridging }\end{array}$ & 2 & 6373 & $1,87(1,03-3,41)$ & 0,04 & NA & & & \\
\hline Chronické srdeční selhání & 6 & 1277 & $1,65(1,14,2,39)$ & 0,008 & NA & & & \\
\hline Perorální antikoagulancia & 9 & 8527 & $1,59(1,01,2,48)$ & 0,04 & 3 & 7271 & $1,18(0,44,3,11)$ & 0,75 \\
\hline \multicolumn{9}{|l|}{ Faktory spojené s výkonem } \\
\hline Trvání výkonu & 9 & 4850 & $9,89(0,52,19,25)$ & 0,04 & 6 & 4508 & $13,04(-0,64,26,73)$ & 0,06 \\
\hline Hematom & 12 & 14228 & $8,46(4,01,17,86)$ & $<0,000001$ & 6 & 9715 & $9,33(2,84,30,69)$ & 0,0002 \\
\hline Repozice elektrody & 5 & 1755 & $6,37(2,93,13,82)$ & 0,000003 & 4 & 1659 & $7,03(2,49,19,85)$ & 0,0002 \\
\hline Nezkušený operatér ${ }^{c}$ & 2 & 1715 & $2,85(1,23,6,58)$ & 0,01 & 2 & 1715 & $2,85(1,23,6,58)$ & 0,01 \\
\hline Dočasná stimulace & 10 & 10683 & $2,31(1,36,3,92)$ & 0,002 & 4 & 8683 & $3,29(1,87,5,80)$ & 0,00004 \\
\hline Úprava polohy/revize/upgrade & 26 & 21214 & $1,98(1,46,2,70)$ & 0,00001 & 8 & 8793 & $0,95(0,49,1,87)$ & 0,89 \\
\hline Výměna přístroje & 20 & 12134 & $1,74(1,22,2,49)]$ & 0,002 & 6 & 2139 & $0,91(0,37,2,22)$ & 0,83 \\
\hline Antibiotická profylaxe & 16 & 14166 & $0,32(0,18,0,55)^{d}$ & 0,00005 & 11 & 10864 & $0,29(0,13,0,63)$ & 0,002 \\
\hline \multicolumn{9}{|l|}{ Faktory spojené s přístrojem } \\
\hline Epikardiální elektrody & 3 & 623 & $8,09(3,46,18,92)$ & 0,000001 & NA & & & \\
\hline Břišní kapsy & 7 & 4017 & $4,01(2,48,6,49)$ & $<0,000001$ & 2 & 2268 & $5,03(1,96,12,91)$ & 0,0008 \\
\hline Více než dvě elektrody & 6 & 1146 & $2,02(1,11,3,69)$ & 0,02 & NA & & & \\
\hline Dvoudutinové přístroje & 14 & 45224 & $1,45(1,02,2,05)$ & 0,04 & 7 & 12102 & $1,28(0,73,2,25)$ & 0,38 \\
\hline
\end{tabular}

Jsou uvedeny rizikové parametry, které byly statisticky významné pro retrospektivní a perspektivní data. Jsou také zobrazeny analýzy omezené na prospektivní data pouze pro stejné parametry (jsou-li k dispozici).

CHOPN - chronická obstrukční plicní nemoc; NA - není k dispozici; NYHA - New York Heart Association.

${ }^{a}$ Glomerularní filtrace (GFR) $\leq 15 \mathrm{ml} / \mathrm{min} / 1,73 \mathrm{~m}^{2}$ nebo hemodialýza nebo peritoneální dialýza

${ }^{b} \mathrm{GFR}<60 \mathrm{ml} / \mathrm{min} / 1,73 \mathrm{~m}^{2}$ nebo clearance kreatininu $(\mathrm{CrCl})<60 \mathrm{ml} / \mathrm{min}$. 'Méně než 100 předchozích procedur.

d Souhrnný odhad účinku z randomizované studie byl $0,26(0,13,0,52)$.

stimulace nebo terapie pozitivně chronotropními léky. Výměna př́stroje zhruba zdvojnásobuje riziko infekce, pravděpodobně v důsledku aktivace již existující bakteriální kolonizace nebo sníženého pronikání antibiotik do zapouzdřené kapsy př́stroje. Stejně jako u každého jiného výkonu má zkušenost dopad na výsledek a riziko infekce může být zvýšeno prováděním výměn přístrojů nezkušenými operatéry.

Existuje méně faktorů souvisejících se zařizením ve vztahu k infekci CIED. Po restrikci analýzy na prospektivní studie byla břišní kapsa vyhodnocena jako jediný významný rizikový faktor, i když faktory, jako je profil pacienta a typ intervence, mohly výsledky zkreslit. Data z Dánského registru ukázala, že komplikovanost zaříze- ní a počet elektrod byly faktory významně spojené se zvýšeným rizikem infekce dle mnohorozměrné analýzy s poměrem rizik (HR) $1,26,1,67$ a 2,22 u systémů $I C D$, biventrikulárních kardiostimulátorů (CRT-P) a srdeční resynchronizační terapie s defibrilátorem (CRT-D), v tomto pořadí, ve srovnání $s$ kardiostimulátory $(p<0,002$ pro všechna srovnání).

\section{Stratifikace rizika}

Vzhledem $\mathrm{k}$ tomu, že $\mathrm{k}$ infekcím CIED dochází $\mathrm{v}$ přítomnosti více faktorů souvisejících jak s pacientem, tak s výkonem, bylo vyvinuto rizikové skóre pro identifikaci pacientů s nízkým a vysokým rizikem. Bodovací systémy 
Tabulka 4 - Seznam doporučených preventivnich opatření pro infekce CIED

Konsenzuální stanovisko

Tř́ída

Kódování

stanoviska vědecké evidence

Opatření před výkonem

Zvážit indikaci k implantaci př́stroje

Odložit implantaci CIED u pacientů s infekcí

Vyhnout se dočasné transvenózní stimulaci a centrálním žilním katétrům, které by měly být pokud možno odstraněny před zavedením nového přístroje

Jsou doporučena opatření, jak zamezit vzniku hematomu kapsy př́stroje (vyhnout se bridgingu heparinem, přerušení protidestičkové léčby, pokud je to možné)

Periprocedurální užívání léčebné dávky nízkomolekulárního heparinu

Proved'te implantaci zařízení na operačním sále v kompletně sterilním prostředí, jako je vyžadováno i pro jiné implantační chirurgické výkony

Výkon by měl být prováděn nebo být proveden pod dohledem operatéra s dostatečným výcvikem a zkušenostmi (tabulka 12)

Může být provedena lokální dekolonizace $S$. aureus

Před výkonem může být provedeno antimikrobiální mytí kůže

Je doporučeno odstranění chloupků pomocí elektrického strojku (ne břitvy)

Antibiotickou profylaxi se doporučuje podat do jedné hodiny po incizi pro cefazolin a flucloxacillin, do 90-120 minut pro vancomycin

Každé implantační centrum by mělo mít program nepřetržitého sledování výskytu infekce a souvisejících mikrobiologických nálezů

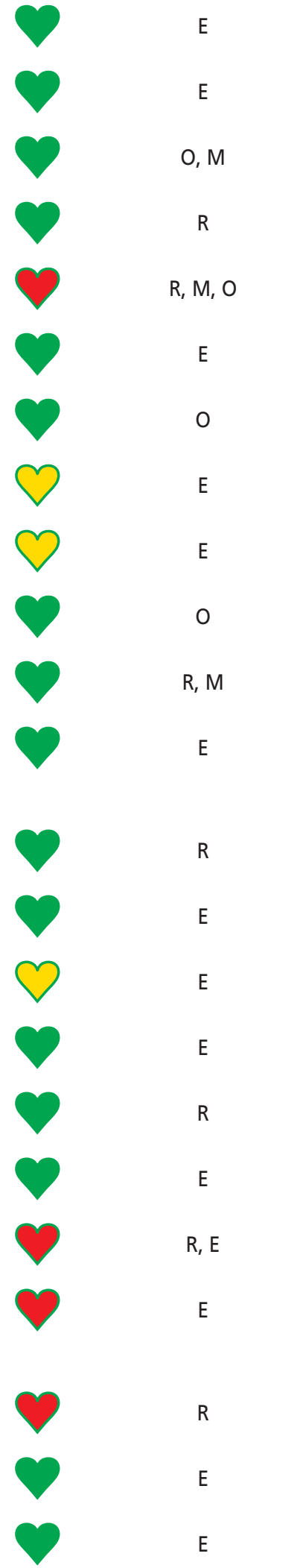

Periprocedurální opatření

K přípravě operačního pole by měl být používán alkoholový chlorhexidin spíše než jod-povidon

Nechte antiseptický př́pravek dostatečně vyschnout

Mohou být použity incizní roušky impregnované jodovými antiseptiky

Proved'te výkon odpovídající chirurgickou technikou - minimalizace poškození tkáně, hemostáza, správné uzavření rány

Ve vysoce rizikových situacích je doporučena antibiotická obálka

Pokud operatér provádí prípravu operačního pole, před prvním řezem si vymění rukavice/znovu dezinfikuje ruce nebo sundá vnější rukavici

Používání lokální instilace antiseptik a antibiotik do kapsy

Použití pletených vláken pro konečné uzavření kůže

Postprocedurální opatření

Použití antibiotické terapie po výkonu

Doporučuje se použití obvazu na dva až deset dní

Pacientům by měly být poskytnuty pokyny, jak pečovat o ránu 
Tabulka 4 - Seznam doporučených preventivních opatření pro infekce CIED

Konsenzuální stanovisko

Třída

stanoviska

Pokud je to možné, znovu zvážit indikaci anebo posunout termín opakované intervence

Drenáž nebo evakuace hematomu (pokud je př́tomno napětí a dehiscence jizvy nebo je výrazná bolest)
Kódování vědecké evidence $\mathrm{E}$

a Kandidáti jsou ti, které definuje studie WRAP-IT10 (pacienti podstupující revizi kapsy nebo elektrody, výměnu př́stroje, upgrade systému nebo primoimplantaci systému CRT-D) a pacienti s dalšími velkými riziky, jak je zvýrazněno v tabulce 3, také je ke zvážení místní výskyt infekce CIED. CIED - srdeční implantabilní elektronické zařízení; E - odborné stanovisko; M - metaanalýza; O - observační studie; R randomizovaná studie.

Hodnocení rizikových faktorů pro infekci CIED

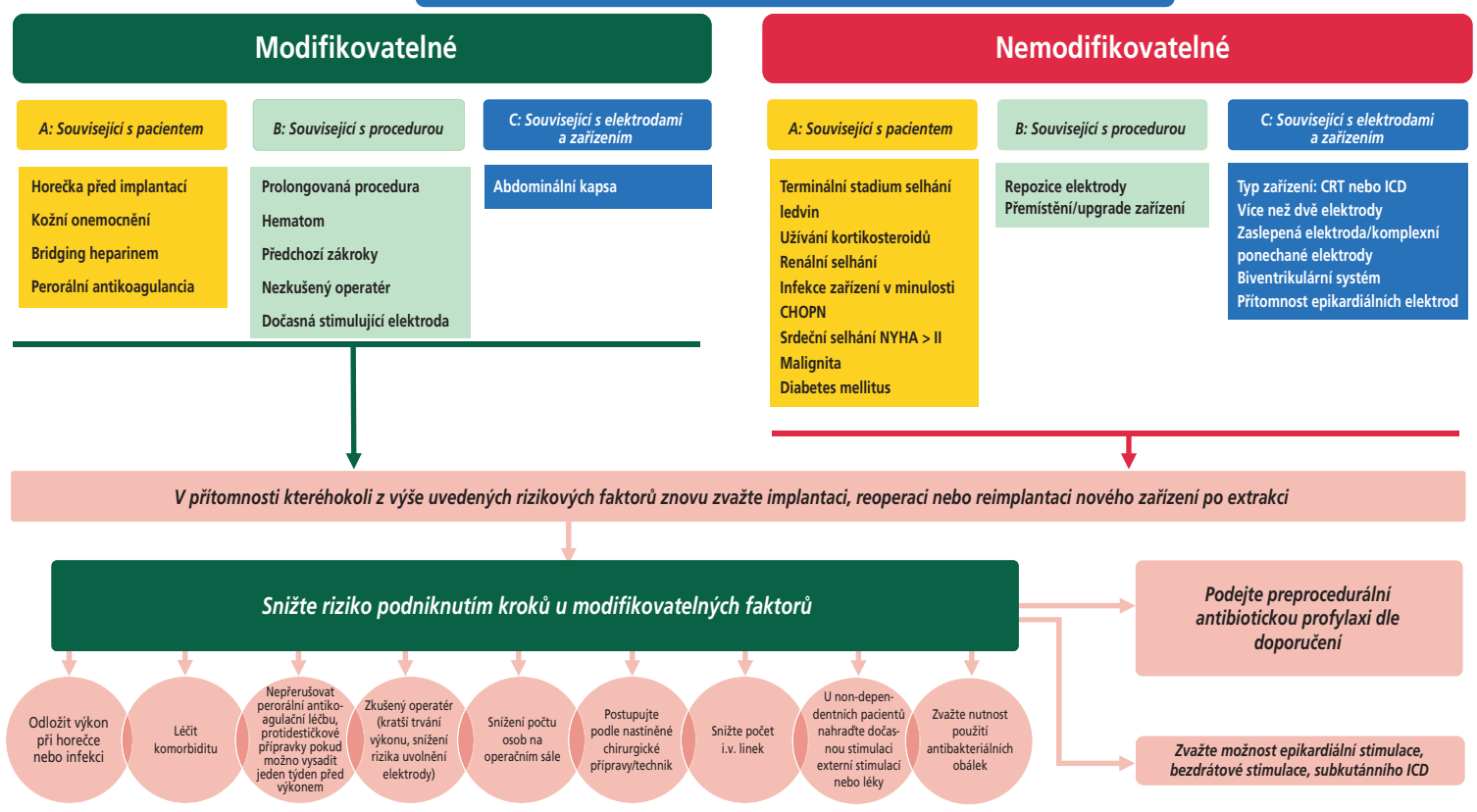

Obr. 1 - Evaluace rizikových faktorů pro infekci CIED. Vývojový diagram ukazující, jak Ize infekce související se zařízením minimalizovat zaměřením se na modifikovatelné rizikové faktory na různé úrovni. Rizikové faktory byly řazeny podle síly odshora dolů.

CIED - srdeční implantabilní elektronické zařízení; CRT - srdeční resynchronizační léčba; CHOPN - chronická obstrukční plicní nemoc; ICD implantabilní kardioverter-defibrilátor; i.v. - intravenózní; NYHA - New York Heart Association; OAC - perorální antikoagulace.

by mohly hrát roli v lepší identifikaci rizikových pacientů než jednotlivé faktory, zejména s ohledem na nekonzistenci hlášených faktorů v různých studiích. Studie jednoho centra s 2891 prríjemci implantabilního defibrilátoru nebo zařízení CRT identifikovala nové kompozitní skóre sedmi nezávislých rizikových faktorů infekce a definovala pacienty v nízkém (1\% riziko), středním $(3,4 \%)$ a vysokém $(11,1 \%)$ riziku infekce. Vzhledem k malému predikčnímu rozsahu nebyl model prijat pro stratifikaci rizika. Další studie identifikovala deset předoperačních rizikových faktorů spojených s infekcí CIED pro systém hodnocení rizika, který definoval skóre méně než 1 jako nízké riziko (1\%) a více než 3 jako vysoké riziko (míra infekce 2,4 \%). Navzdory potenciálu k praktickému využití tohoto skóre jej v současné době nelze doporučit, protože důkazy zůstávají slabé.

\section{Prevence}

Přehled doporučených preventivních opatření je uveden v tabulce 4. Vývojový diagram, který ukazuje, jak Ize modifikovatelné rizikové faktory minimalizovat na různých úrovních, je znázorněn na obrázku 1.

\section{Opatření před výkonem}

\section{Zvážení indikace}

Nejlepší léčbou infekcí souvisejících s implantabilními přístroji je prevence. Je třeba pečlivě zvážit, zda riziko implantace př́stroje u každého jednotlivého pacienta nepřeváží nad prínosem. Pokud existuje významné riziko infekce, může být užitečné odložení implantace s další 
observací nebo prodloužení antibiotické léčby. U pacientů podstupujících extrakci prístroje pro infekci, nemusí jedna třetina až jedna polovina vyžadovat opakovanou implantaci. Pokud se rozhodneme provést implantaci, je důležité „myslet, než si vyberete”. U vysoce rizikových pacientů může být výhodné vyhnout se transvenóznímu systému a implantovat epikardiální systém. Existuje naděje, že bezelektrodové kardiostimulátory budou méně náchylné k infekci a mohou být podobným způsobem použity u vysoce rizikových pacientů. Subkutánní defibrilátory (S-ICD) jsou alternativou u pacientů vyžadujících ochranu před náhlou srdeční smrtí, pokud nevyžadují stimulaci. Rozhodnutí musí být učiněna individuálně, přičemž musejí být zvážena všechna známá rizika a přínosy.

\section{Management elektrod}

Počet elektrod a prítomnost zaslepených elektrod je spojena se zvýšeným rizikem komplikací, včetně infekce. Rozhodnutí zaslepit nebo extrahovat elektrodu může být složité a musí být učiněno individuálně s uvážením všech známých rizik a prínosů. V tomto rozhodnutí musí být zahrnuto také zvýšené riziko infekce a zvýšené riziko extrakce, pokud k infekci dojde.

\section{Faktory spojené s pacientem}

U pacientů, kteří mají horečku nebo známky aktivní infekce, by měl být zákrok odložen, dokud nebude pacient afebrilní po dobu nejméně 24 hodin. Potřeba dočasných stimulačních elektrod zvyšuje riziko infekce, a pokud je to možné, je třeba se jí vyhnout. Dočasná stimulace cestou jugulární žíly může poskytnout nižší riziko infekce než přístup přes tříslo, ačkoli toto musí být ještě prověřeno. Studie prokázaly, že lepší kontrola glykemie v periprocedurálním období může snížit riziko infekce.

\section{Antikoagulační a protidestičková léčba}

Tvorba hematomu kapsy zvyšuje riziko infekce. Studie prokázaly, že „bridging” antikoagulace zvyšuje riziko hematomu a již se nedoporučuje. U pacientů, kteří nejsou ve vysokém riziku tromboembolických prríhod (např. skóre $\mathrm{CHA}_{2} \mathrm{DS}_{2}-\mathrm{VASc}<4$ ), se zdá rozumné vysazení antikoagulace během výkonu a opětovné nasazení až po snížení rizika krvácení. U pacientů s vyšším rizikem, jako jsou ti $s$ embolickou príhodou $v$ anamnéze nebo $s$ mechanickou chlopní, se doporučuje pokračovat v antikoagulaci warfarinem. Předběžné údaje ze studie BRUISE-Control 2 naznačují, že totéž mưže platit i pro nová perorální antikoagulancia. Léčbě nízkomolekulárním heparinem (LMWH) bychom se měli vyhnout. Protidestičkové léky, zejména inhibitory P2Y 12 (clopidogrel, prasugrel, ticagrelor), významně zvyšují riziko krvácení a měly by být (pokud nejsou jasně indikovány) vysazeny nejlépe pět až deset dní před výkonem, zejména pokud jsou kombinovány s perorálními antikoagulancii.

\section{Vhodné prostředí}

Na implantačním sále i v elektrofyziologických/katetrizačních laboratořích musejí být splněny standardy pro sterilní výkony (např. úklid, uspořádání místnosti, ventilace, omezený průchod atd.) stejně jako u jiných chirurgických zákroků spojených s implantáty. Byly zveřejněny minimální standardy podmínek při implantaci CIED. Je doporučeno, aby každé centrum zrrídilo program pro nepřetržitý dohled nad svými infekčními komplikacemi a zúčastněnou mikroflórou. Data musejí být korelována s informacemi o pacientovi, výkonu, personálu a typu přístroje (tabulka 4).

\section{Výcvik personálu}

Všichni pracovníci, kteří se podílejí na implantaci CIED, musejí být vyškoleni v příslušných sterilních technikách a chování v prostředí operačních sálů (mytí, príprava sterilních stolků, příprava pacienta a přísné omezení provozu v místnosti). Operatéři by měli být náležitě vyškoleni a měli by být pod dohledem.

\section{Stěry z nosní sliznice/Dekolonizace S. aureus u pacientů}

U elektivních výkonů může být kolonizace $S$. aureus detekována stěrem z nosní sliznice. Ošetření nosu mupirocinem a omýváním kưže chlorhexidinem může snížit kolonizaci a v některých chirurgických studiích bylo prokázáno, že snižuje riziko infekce, ale neexistují žádné studie týkající se konkrétně implantací CIED.

\section{Príprava operačního pole}

V mnoha nemocnicích je před výkonem prováděno mytí kůže antimikrobiálními prostředky. Údaje o tomto postupu pro obecné chirurgické výkony jsou různorodé a doporučení pro jeho rutinní použití proto nelze silně podpořit. Pokud je třeba odstranit chloupky na hrudi (tabulka 4) (obr. 1), měl by k tomu být v den výkonu použit elektrický strojek s jednorázovou hlavou.

\section{Antibiotická profylaxe před výkonem}

Bylo prokázáno, že použití profylaktických intravenózních antibiotik snižuje riziko infekce CIED a je standardní součástí péče. ${ }^{9}$ Významně snižuje výskyt infekce ve srovnání s nepodávanou antibiotickou terapií, s 40-95\% snížením relativního rizika. ${ }^{21}$ Dávka antibiotik musí být podána do jedné hodiny od incize, aby byla zajištěna dostatečná tkáňová koncentrace. Staphylococcus aureus je organismus nejčastěji zapojený do akutních infekcí CIED. Stupeň rezistence na methicilin se liší. Antibiotika by měla pokrýt alespoň $S$. aureus. V současné době neexistují žádná významná data, která by podporovala rutinní pokrytí methicilin rezistentního $S$. aureus (MRSA) a jeho použití by se mělo řídit mírou výskytu MRSA v jednotlivých implantačních centrech a rizikem pacienta. $V$ randomizovaných studiích byly použity i.v. flucloxacilin (1-2 g) a cefalosporiny první generace, jako je cefazolin (1-2 g). Vancomycin (15 mg/kg) Ize použít v prípadě alergie na cefalosporiny a měl by být podáván pomalu (déle než jednu hodinu), a proto musí být podání zahájeno 90-120 minut před prvním řezem.

\section{Opatření během výkonu}

\section{Príprava pacienta $\boldsymbol{k}$ výkonu}

Randomizované studie prokázaly, že alkoholový 2\% chlorhexidin je lepší než povidon-jod (s alkoholem nebo bez alkoholu) pro přípravu kůže před operací nebo intravaskulárním zavedením katétru, ale neexistují žádná randomizovaná data ohledně implantace CIED. Před zahájením výkonu by mělo antiseptikum zcela uschnout, aby bylo 
zajištěno dostatečné množství času k zajištění jeho účinnosti. Kromě toho mohou alkoholická antiseptika predstavovat nebezpečí požáru ve spojení s elektrokauterizací, zejména pokud dojde k tvorbě jezírek dezinfekce. Mnoho operatérů používá incizní fólie, ale neexistuje důkaz, že by tento postup snízil výskyt infekce (a dokonce může být riziko infekce zvýšeno, pokud se použijí roušky bez jodoforu).

\section{Správná chirurgická technika}

Minimalizace poškození tkáně, důsledná hemostáza a adekvátní uzavření rány jsou důležitá opatření $\mathrm{k}$ zabránění vzniku infekce. Mnoho operatérů si vyměňuje rukavice (např. nošením dvojitých rukavic) po zarouškování pacienta a také před manipulací s přistrojem. Nepráškované rukavice mohou snižit riziko infekce snížením lokálního zánětu. Hematom kapsy je spojen se zvýšeným rizikem infekce. Neexistují žádná data podporující rutinní používání lokálních hemostatik, i když u vybraných pacientů mohou být užitečná. Intenzivní vyplachování kapsy je důležité k odstranění devitalizované tkáně a také $\mathrm{k}$ rožredění jakékoli kontaminace. Diagnostická nebo terapeutická aspirace hematomu je kontraindikována vzhledem k riziku „inokulace" kapsy a následnému propuknutí infekce. Evakuace hematomu by měla být prováděna pouze $v$ př́padě, že je bolest nezvládnutelná nebo je ohroženo hojení rány, a v ideálním případě by měla být prováděna na operačním sále.

\section{Antibiotická obálka}

Byla vyvinuta antibakteriální sítová obálka (TYRX'M , Medtronic, MN, USA), která lokálně uvolňuje minocyklin a rifampicin po dobu minimálně sedmi dnů, a brání tak infekci a tvorbě biofilmu a je plně absorbována do devíti týdnů. Studie WRAP-IT ukázala, že obálka významně snižuje výskyt infekce CIED u vysoce rizikových pacientů (podstupujících revizi kapsy nebo elektrody, výměnu prístroje, upgrade systému nebo primoimplantaci CRT přístroje) bez vyššího výskytu komplikací. Celkem 6983 pacientů bylo randomizováno do dvou větví, první větev dostala antimikrobiální obálku a druhá ne, s nižším výskytem primárních cílových ukazatelů (infekce vedoucí $k$ extrakci nebo revizi systému, dlouhodobé antibiotické léčbě nebo úmrtí) do 12 měsíců po implantaci CIED u pacientů, kteří dostali obálku vs. kontrola: $0,7 \%$, respektive 1,2\% (poměr rizik 0,60; $95 \%$ interval spolehlivosti $0,36-0,98 ; p=0,04$ ). Zatímco léčená populace vykazovala prínos, počet léčených pacientů potřebných $\mathrm{k}$ tomu, aby se zabránilo jedné infekci, byl vysoký. Vyloučení pacientů s vyšším rizikem (léčených imunosupresivy, s cévním prístupem nebo na dialýze) může přispět $\mathrm{k}$ nižší než očekávané míře infekcí $(1,2 \%)$, která byla pozorována také v jiných prospektivních studiích. Zvýšené povědomí o prevenci infekce při účasti na prospektivních studiích může také vysvětlit její nízký výskyt. Vyšší podíl infekce (2,3-3,4 \%), jaký byl pozorován v méně selektovaných retrospektivních studiích, by zlepšil celkovou nákladovou efektivitu antimikrobiální obálky. Doporučení pro použití antibakteriální obálky je uvedeno v tabulce 4. Použití by mělo být individualizováno na základě př́tomnosti rizikových faktorů (tabulka 3) a lokálního výskytu infekcí CIED. Použití dalších „obálek“ (biodegredabilních nebo perikardiálních) pro stabilizaci, gázy sycené antibiotiky atd. nebylo náležitě studováno a nelze jej podpořit

\section{Lokální použití antibiotik a antiseptik}

Zatímco intenzivní proplachování kapsy je doporučováno, použití lokálních antibiotik nebo antiseptik vhodné není. Nedávná studie PADIT neprokázala žádný prínos (viz níže).

\section{Kapsulektomie}

I při absenci klinických známek infekce vykazují kultury získané v době výměny přístroje významný výskyt kolonizace. Vazivová tkáň kapsy navíc inhibuje normální obranné mechanismy těla a pronikání antibiotik. Teoreticky by odstranění vaziva mohlo zmírnit tyto překážky, ale může také vést $k$ většímu krvácení do kapsy/tvorbě hematomu, a proto jej nelze doporučit jako běžnou praxi.

\section{Uzávěr rány}

Dehiscence nebo povrchová infekce rány může vést $k$ infekci kapsy. Uzavření ve vrstvách minimalizuje napětí rány a snižuje riziko dehiscence a infekce. Uzavření kůže může být provedeno intradermálním vstřebatelným stehem, nevstřebatelným stehem, chirurgickými sponkami nebo chirurgickým lepidlem. Pokud se používá neabsorbovatelný materiál, musí být v příhodný čas odstraněn, dle aktuálního klinického nálezu (obvykle 7-14 dní). Vstřebatelné stehy musejí být vhodně umístěny tak, aby bylo umožněno vstřebávání a aby nedošlo k „abscesu stehu“, zejména v místě uzlu. Přestože neexistují žádná data naznačující, že typ šicího materiálu ovlivňuje riziko infekce, mnoho operatérů upřednostňuje pro uzavření kůže netkaná monofilamenta, protože se tím vyhnou možné bakteriální adhezi (viz oddíl Patogeneze a mikrobiologie infekcí srdečních implantabilních elektronických zařízení). Některé stehy jsou impregnovány antibiotiky, ale protože neexistují žádné důkazy o tom, že tím snižují riziko infekce, neIze je doporučit jako lepší než standardní stehy.

\section{Opatření po výkonu}

\section{Antibiotická terapie po výkonu}

Někteří lékaři podávají antibiotika po implantaci v různém rozsahu, od jednorázového podání po výkonu po týdenní i.v. a perorální podávání. Nedávná shlukově randomizovaná studie PADIT 9 se zkř́ženým uspořádáním testovala klinickou účinnost různých dávek perioperačního podání antibiotik za účelem snížení infekce zařízení. Konvenční léčbou byla jednorázová předoperační infuze cefazolinem vs. kombinace preprocedurálního cefazolinu plus vancomycinu, intraprocedurální mytí bacitracinem v kapse a dvoudenní pooperační perorální cephalexin u téměř 20000 pacientů podstupujících implantaci CIED. Primární výsledný ukazatel ročních hospitalizací pro infekci zařízení ve vysoce rizikové skupině nebyl statisticky významný (nevýznamné 20\% snížení infekce). Počet infekcí zařízení byl nízký. Protože neexistují žádné údaje podporující tuto praxi, nedoporučuje se podávat pooperační antibiotickou terapii.

\section{Péče o ránu}

V závěru operace by mělo být použito vhodné krytí rány (s výjimkou případů použití chirurgického lepidla). Toto krytí bývá dle klinické praxe ponecháno po dobu dvou až deseti dnů. Po dobu prvních 24 hodin mohou být pou- 
Tabulka 5 - Doporučení pro diagnostiku infekce CIED a/nebo infekční endokarditidy: Nová mezinárodní kritéria pro infekci CIED 2019

\section{Konsenzuální stanovisko Trída stanoviska Kódování vědecké evidence}

,Potvrzená' infekce kapsy CIED = kapsa přístroje je oteklá, zarudlá, hřeje, je př́itomna bolest a hnisavý výtok/formuje se dutina NEBO je přítomna deformace kapsy a hrozící dekubitus NEBO je odhalen přístroj nebo proximální část elektrody

,Potvrzená' CIED/IE = přítomnost bud' dvou velkých kritérií, nebo jednoho velkého a tří malých kritérií

,Možná' CIED/IE = přítomnost bud' jednoho velkého a jednoho malého kritéria, nebo tří malých kritérií

'Vyloučená' diagnóza CIED/IE = pacient nesplňuje výše uvedená kritéria pro IE

Velká kritéria

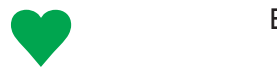

Mikrobiologický nález A. Nález bakterií v hemokultuře typických pro infekci CIED a/nebo IE (koaguláza-negativní stafylokoky, S. aureus) B. Mikroorganismy konzistentní s IE ze dvou různých hemokultur:

a. Viridující streptokoky, Streptococcus gallolyticus (S. bovis), skupina HACEK, S. aureus nebo

b. komunitně získané enterokoky v nepřítomnosti primárního ložiska

C. Mikroorganismy konzistentní s IE z trvale pozitivních hemokultur:

a. Dvě a více pozitivní hemokultury z odběrů v rozmezí $>12 \mathrm{~h}$ nebo

b. všechny tři nebo většina z čtyř a více separátních hemokultur (první a poslední odběr v rozmezí více než jedné hodiny) nebo

C. jediná pozitivní hemokultura Coxiella burnetii nebo titr protilátek IgG fáze I > $1: 800$

Zobrazování pozitivní pro infekce CIED a/nebo IE

D. Echokardiogram (včetně ICE) pozitivní pro:

a. infekci CIED:

i. Klinické známky infekce kapsy přístroje

ii. Vegetace na elektrodě

b. chlopenní postižení při IE

i. Vegetace

ii. Absces, pseudoaneurysma, intrakardiální píštěl

iii. Perforace nebo aneurysma chlopně

iv. Nová částečná dehiscence chlopenní náhrady

E. Abnormální aktivita v okolí kapsy přístroje, kolem elektrod nebo na chlopni detekována [18F]FDG PET/CT (pozor bychom měli dávat v př́padech nedávné implantace př́istroje) nebo scintigrafií značenými leukocyty

F. Jednoznačná paravalvulární léze na CT srdce

Malá kritéria

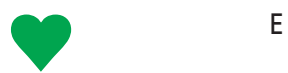

a. Predispozice, jako je predisponující srdeční onemocnění (např. nově vzniklá trikuspidální regurgitace) nebo užívání intravenózních drog

b. Horečka (teplota $>38^{\circ} \mathrm{C}$ )

c. Cévní fenomény (včetně těch detekovaných zobrazovacími metodami): velké arteriální emboly, septické plicní infarkty, infekční (mykotické) aneurysma, intrakraniální krvácení, konjuktivální krvácení a Janewayovy léze

d. Mikrobiologický průkaz: pozitivní hemokultura, která nesplňuje výše uvedená velká kritéria nebo serologický průkaz aktivní infekce organismem konzistentním s IE nebo kultivace z rány nebo z elektrody (která byla extrahována přes neinfekční kapsu)

Na základě sloučení modifikovaných Duke kritérií a Doporučených postupů ESC pro léčbu IE 2015 viz text. Zelený text odkazuje na kritéria infekce spojená s CIED.

CIED - srdeční implantabilní elektronická zařízení; CT - výpočetní tomografie, E - odborné stanovisko; ICE - intrakardiální echokardiografie; IE - infekční endokarditida; M - metaanalýza; O - observační studie; R - randomizované studie; SPECT - jednofotonová emisní výpočetní tomografie.

žity tlakové obvazy, aby se zabránilo vzniku hematomu. Obvaz není nutné měnit, pokud není prosáklý. Některé obvazy jsou vodotěsné a umožňují pacientovi se osprchovat. Pacienti by měli být upozorněni, aby se vyhnuli promáčení rány (např. plaváním), dokud není zcela zahojená (což obvykle trvá přibližně měsíc). Měli by také být poučeni o vyhledání lékařské pomoci v případě známek lokální infekce.

\section{Revize}

Je dobře známo, že časná revize dramaticky zvyšuje riziko infekce, takže je třeba prijimout veškerá opatření, aby se této události zabránilo (tj. prevence hematomu, prevence dislokace elektrody atd.). Někteří operatéři kvưli riziku infekce záměrně odkládají revizi až v řádu týdnů (např. pro repozici elektrody). Je možné, že tento přístup také zmírní bolestivost spojenou s dalším zásahem, ale pro potvrzení této teorie je ještě nutný podrobnější výzkum.

\section{Diagnóza infekce srdečních implantabilních elektronických zařízení a související komplikace}

\section{Klinické nálezy}

Povrchová infekce rány by měla být odlišována od infekce kapsy, protože zahrnuje pouze kůži a podkožní tkáň bez komunikace s kapsou (a proto nevyžaduje extrakci systému CIED). Je třeba pacienta pečlivě sledovat, aby bylo možné rozpoznat časnou recidivu, která může být známkou významné infekce kapsy. 
Infekce kapsy je definována jako infekce omezená na kapsu generátoru. Je klinicky spojena s lokálními známkami zánětu, které mohou být mírné a vyznačují se zarudnutím, proteplením a fluktuací. Deformace kapsy, srůsty nebo hrozící eroze jsou často př́iznaky indolentní infekce nízkého stupně. Příznaky infekce chirurgické rány se mohou různit, a ačkoli může být zpočátku obtížné ji rozpoznat, nedoporučuje se odebírat vzorek materiálu z kapsy. Jakmile dojde $\mathrm{k}$ dehiscenci rány, vytvoří se hnisavý drenážní kanál nebo sinus a infekce kapsy je jasně přítomna. Pokud je navenek obnažen generátor nebo proximální elektrody, mělo by být zařízení považováno za infikované, bez ohledu na výsledky mikrobiologického vyšetření. Pro rozpoznání potenciálních kontaminantů může být pro kultivaci použit materiál z kapsy. Infekce kapsy mohou být spojeny $s$ infekcemi elektrod a systémovými infekcemi CIED a/nebo infekční endokarditidou. Skutečný počet infekcí závisí na definicích použitých v různých studiích. Diagnóza systémové infekce CIED a infekční endokarditidy bez lokální infekce může být náročnější (tabulka 5). Př́znaky mohou být nespecifické (horečka, zimnice, noční pocení) a mezi implantací CIED a nástupem př́znaků a stanovením diagnózy může uplynout dlouhá doba. Pacienti s infekcí CIED mohou mít embolické postižení plic a pleurálního prostoru, často nesprávně diagnostikované jako plicní infekce. Infekce elektronických implantabilních srdečních zařízení mohou být také odhaleny skrze jiná vzdálená ložiska, jako jsou vertebrální osteomyelitida a spondylodiscitida. C-reaktivní protein (CRP) může být užitečný, i když nespecifický, a stanovení prokalcitoninu (PCT) může pomoci zejména, pokud je pozitivní $(>0,05)$ kvůli vysoké specificitě pro infekci kapes ve srovnání s chybějící infekcí a v případě embolických jevů a endokarditidy způsobené $S$. aureus.

Neexistuje žádný standardizovaný diagnostický nástroj pro endokarditidu CIED. V současné době jsou jediným dostupným prostředkem pro diagnostiku endokarditidy CIED modifikovaná Dukeova kritéria a kritéria ESC pro infekční endokarditidu z roku 2015. Avšak ani jeden z nich nepředstavuje ověřený a standardizovaný nástroj pro diagnostiku v tomto konkrétním príípadě. $V$ zájmu zvýšení citlivosti pro diagnostiku infekce CIED tento panel doporučuje přidat další kritéria a sloučit modifikovaná Dukeova kritéria s kritérii ESC z roku 2015. Jako výsledek tohoto postupu byla vyvinuta Mezinárodní kritéria infekce CIED 2019, která jsou podrobně uvedena v tabulce 5.

\section{Identifikace příčinných mikroorganismů}

Identifikace mikroorganismů, které způsobily infekci CIED, je klíčová pro účinnou antibiotickou terapii (tabulka 2). Proto by mělo být vynaloženo veškeré úsilí pro získání hemokultur před zahájením antibiotické terapie. Hemokultury by se měly opakovat u pacientů s CIED a horečkou bez jasných známek lokálních infekcí a u pacientů s infekční endokarditidou. Před zahájením léčby antibiotiky by měly být odebrány tři sady hemokultur (mezi nimi odstup alespoň 30 minut, tabulka 6). Více sad hemokultur $v$ různých časových intervalech umožňuje rozlišovat mezi přechodnou a přetrvávající bakteriemií a zvyšuje citlivost. U stabilních pacientů může dvou- až třídenní období bez antibiotické terapie zvýšit přesnost mikrobiologické diagnózy. $U$ nestabilních pacientů $v$ sepsi nebo septickém šoku by měla být včasná empirická antibiotická terapie

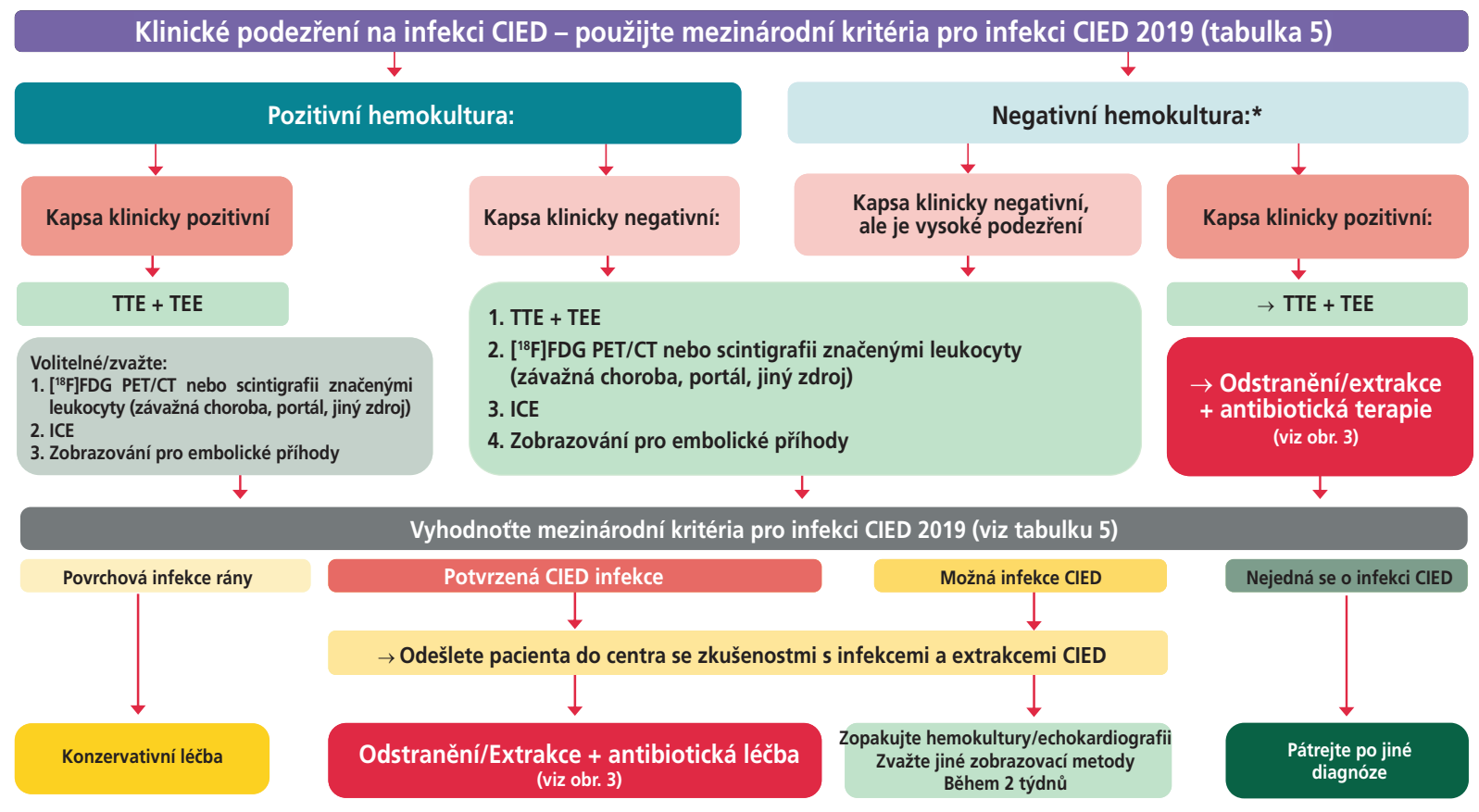

Obr. 2 - Diagnostický algoritmus při podezření na infekce CIED.

* Zajistěte dostatečný počet odebraných hemokultur a nepř́tomnost matoucí antibiotické terapie před odběrem.

CIED - srdeční implantabilní elektronické zařízení; [ ${ }^{18}$ F]FDG PET/CT - pozitronová emisní tomografie/výpočetní tomografie s podáním fluorodeoxyglukózy značené fluorem-18; ICE - intrakardiální echokardiografie; IE - infekční endokarditida; TEE - transezofageální echokardiografie; TTE - transtorakální echokardiografie; WBC SPECT/CT - jednofotonová scintigrafie značenými leukocyty/výpočetní tomografie. 
Tabulka 6 - Doporučení pro diagnostiku infekcí CIED dle klinického nálezu a mikrobiologie

Konsenzuální stanovisko
tři sady hemokultur
Měly by být provedeny stěry z kapsy, ale pouze pokud byly získány při vyjmutí přístroje,
ne z dutin nebo píštělí
V případě spondylodiscitidy a/nebo septických embolizací do plic (klinické známky a symptomy
systémových infekcí CIED mǔže být obtížné rozpoznat, protože může být prítomna pouze
horečka) je nutné vyslovit podezření na infekci CIED
Měla by být provedena kultivace extrahovaných elektrod a přístroje
Určení koncentrace prokalcitoninu může být užitečné v případě infekční endokarditidy a embolie
a/nebo v případě infekční endokarditidy související s CIED zpưsobené S. aureus
Mưže být zváženo prodloužení doby inkubace (10-14 dní) u pomalu rostoucích mikroorganismů
v př́ípadě infekční endokarditidy související s CIED a přetrvávajícími negativními hemokulturami
Užitečnost sonikace CIED pro zlepšení mikrobiologické detekce při extrakci je stále evaluována,
ale múže být použita s opatrností při interpretaci
Stěry z dutiny kapsy CIED nebo z vyhřezlých částí přístroje

CIED - srdeční implantabilní elektronické zařízení; E - odborné stanovisko; O - observační studie.

zahájena po dvou souborech krevních kultur, aby se nezdržel začátek jejího podání. Pro zvýšení citlivosti musejí být lahvičky s krví řádně naplněny (tabulka 5). Povinná je aseptická technika odběru hemokultur, protože bakterie běžně považované za kontaminanty kưže jsou častými původci infekcí CIED. Každá pozitivní hemokultura, včetně jedné lahvičky s koaguláza-negativními stafylokoky nebo jinými grampozitivními organismy, by měla být pečlivě vyhodnocena a je nutné okamžitě aktivně vyhledávat a vyloučit infekci CIED pomocí dalších diagnostických technik (obr. 2). $\mathrm{V}$ prípadě přetrvávajících negativních hemokultur (obvykle pět dnů, tabulka 6) a přítomné endokarditidy CIED Ize zvážit prodloužení inkubační doby na 10-14 dnů a použití biomolekulárních metod (amplifikace DNA a/nebo sekvenování genů) pro detekci náročných nebo atypických patogenů. Mezi grampozitivními mikroorganismy existují druhy, které mohou vyžadovat delší inkubační dobu, jako je Cutibacterium (dříve Propionbacterium) acnes, zejména $v$ anaerobních podmínkách (tabulka 6). Předpokládá se, že $S$. aureus může být spojován s ranějšími infekcemi a s infekční endokarditidou, ve srovnání s jinými patogeny, ale data jsou stále nekonzistentní. Závažnější případy mohou být způsobeny $S$. aureus a gramnegativními tyčinkami.

Pro kultivaci se nedoporučují výtěry odebrané z chronického drenážního sinu nebo píštěle (tabulka 6), místo toho je vhodné odebrat tkáň nebo tekutinu prímo z kapsy (prostřednictvím sterilní jehly nebo stříkačky), a to prístupem přes sousedící nepoškozenou kưži, aby se zabránilo průchodu drenážní dutinou. Př́stup skrze sinus by měl být použit pouze pro stanovení bakteriální diagnózy, nikoli ke stanovení prítomnosti infekce kapsy. Je třeba se vyvarovat vstupu do neporušené kapsy, aby nedošlo k zanesení bakteriemi.

Během extrakce by ke kultivaci měly být zaslány distální a proximální fragmenty elektrod, vegetace elektrod (pokud je př́tomna) a tkáň kapsy generátoru (tabulka 6). Gramovo barvení je stále považováno za vhodné, stále častěji se navíc používají biomolekulární metody, které mohou být specifičtější. Navrhovaná kultivační média jsou čokoládový agar inkubovaný v 5\% $\mathrm{CO}_{2}$ po dobu 48-72 hodin, MacConkeyho agar inkubovaný po dobu 48 hodin, krevní agar inkubovaný v anaerobním prostředí po dobu 48-72 hodin a Sabouraudův agar inkubovaný po dobu 5 dnů. Úzká spolupráce s místní mikrobiologickou laboratoří je důležitá pro zvýšení diagnostického výnosu. V případě odběru hnisu, který ani po třech dnech nevykazuje známky bakteriálního rưstu, je třeba zvážit pomalu rostoucí mikroorganismy včetně $C$. acnes a prodloužit dobu inkubace. Kromě výtěrů se u pacientů s klinickými známkami infekce dají pro zisk bakterií z CIED použít vzorky tkáně a metoda sonikace (proces destrukce buněčné stěny pomocí vysokofrekvenčních ultrazvukových vln), i když tato metoda si ještě zaslouží další výzkumnou studii.

\section{Zobrazovací metody}

\section{Echokardiografie}

Echokardiografie by měla být první zobrazovací metodou při hodnocení pacientů s CIED s cílem identifikovat vegetace elektrod a postižení chlopní. V prrípadě podezření na infekci CIED je možné použít jak transtorakální (TTE), tak transezofageální echokardiografii (TEE). Zatímco TTE lépe stanoví perikardiální výpotek, ventrikulární dysfunkci a plicní vaskulární tlak, TEE je lepší pro detekci a dimenzování vegetací, zejména v oblasti pravá síň-v. cava superior a v oblastech méně dobře vizualizovaných pomocí TTE. Transtorakální i transezofageální echokardiografie však mohou být falešně negativní u infekční endokarditidy související s CIED v nepř́tomnosti typických vegetací měřitelné velikosti. Př́tomnost nejasných formací na 


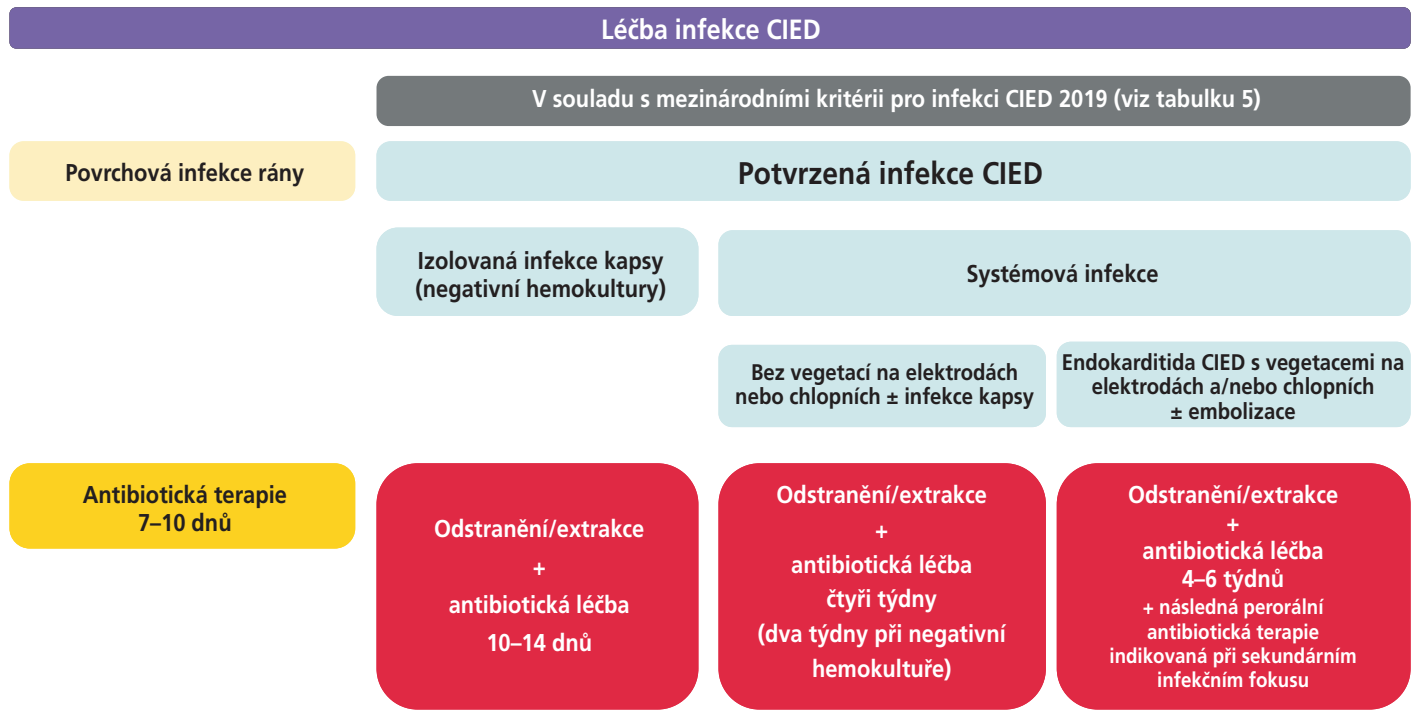

Obr. 3 - Léčebné strategie pro pacienty s infekcemi CIED. CIED - srdeční implantabilní elektronické zařízení.

elektrodách může být při TTE/TEE zachycena i u asymptomatických nosičů CIED a dle dlouhodobého sledování nepredikuje infekční endokarditidu spojenou s CIED. Proto při zachycení jakékoli masy na elektrodě je třeba pečlivé klinické posouzení, včetně sériových TTE/TEE nebo dalších zobrazovacích testů, aby se vyloučila infekce nebo nebakteriální trombotická endokarditida elektrody.

Intrakardiální echokardiografie (ICE) je účinná a má vysokou citlivost pro detekci vegetací u srdečních zařízení. Proto Ize vegetaci pozorovanou u ICE považovat za hlavní kritérium diagnózy (tabulka 5). Nedávno se ukázalo, že pro odlišení vegetace od trombu je užitečná transvenózní biopsie řízená TEE (obr. 2).

U pacientů s infekcemi CIED léčených perkutánní extrakcí elektrod se před propuštěním z nemocnice doporučuje provést TTE $k$ detekci případných zbylých fragmentů elektrod a k posouzení funkce trikuspidální chlopně, funkce pravé komory a plicní hypertenze. Zejména u pacientů s pretrvávající sepsí po perkutánní extrakci elektrod by se mělo zvážit provedení jícnové echokardiografie (a dalších zobrazovacích testů) ke zjištění infikovaného materiálu, duchů a potenciálních komplikací trikuspidální chlopně (tabulka 7). Je důležité si uvědomit, že normální echokardiografie nevylučuje infekční endokarditidu související s CIED.

\section{Scintigrafie značenými leukocyty, pozitronová emisní tomografie a výpočetní tomografie}

U komplexních prípadů jsou doplňujícími metodami pro diagnózu infekce spojené s CIED a přidružených komplikací pozitronová emisní tomografie/výpočetní tomografie S podáním fluorodeoxyglukózy značené fluorem-18 ([18 F] FDG PET/CT) a scintigrafie značenými leukocyty (WBC). Obě zobrazovací techniky poskytují další diagnostickou hodnotu, zejména $v$ podskupině možných infekcí CIED, a mohou rozlišovat mezi časnou povrchovou infekcí rány a skutečnou infekcí kapsy generátoru nebo rozlišit povrchovou a hlubokou infekci kapsy. Pokud pacienti jeví pouze celkové známky infekce bez lokálního nálezu v místě kapsy generátoru, je diagnóza infekce elektrody velmi náročná a $v$ tomto případě je použití $\left[{ }^{18} \mathrm{~F}\right] \mathrm{FDG}$ PET/CT velmi užitečné (poolovaná specificita $93 \%[95 \% \mathrm{Cl}$ 0,84-0,98] a poolovaná senzitivita $98 \%$ [95\% Cl 0,88-1,00] a plocha AUC pod křivkou 0,98 při analýze ROC). Mírné zánětlivé změny po implantaci zařízení obvykle nepřesahuji šest týdnů a po tomto období se dají snadno odlišit od infekce. Scintigrafie bílých krvinek včetně jednofotonové emisní tomografie/výpočetní tomografie (SPECT/CT) má vysokou senzitivitu a specificitu pro detekci a lokalizaci infekcí souvisejících s CIED (94\% a $100 \%$, v tomto pořadí, v největší studii). V případě infekční endokarditidy související s CIED jsou $\left[{ }^{18}\right.$ F]FDG PET/CT a scintigrafie značenými leukocyty velmi specifické, pokud je vstřebávání indikátoru vizualizováno (jen pokud je aplikován s odstupem po implantaci), ačkoli negativní výsledek nevylučuje úplně přítomnost malých vegetací s nízkou metabolickou aktivitou (tj. omezená citlivost a negativní prediktivní hodnota). Proto je diagnostická přesnost pro infekce elektrod nižší, s celkovou poolovanou senzitivitou $65 \%(95 \% \mathrm{Cl} 0,53-0,76)$, specificitou $88 \%(95 \% \mathrm{Cl} 0,77-0,94)$ a plochou AUC pod křivkou 0,861. $\left[{ }^{18} \mathrm{~F}\right]$ FDG PET/CT má schopnost hodnocení celého těla, a proto se ukázalo jako zvláště užitečné pro identifikaci nezvyklých embolických lokalizací a metastatických infekcí, včetně mykotických aneurysmat, slezinných a plicních embolií a spondylodiscitidy (nikoli embolie mozku). To má vliv na Dukeova kritéria, diagnostickou jistotu a management léčby. Kromě toho je identifikace infekčního místa pomocí PET/CT a značených leukocytů rozhodující pro prevenci relapsu infekční endokarditidy. Pozitronová emisní tomografie/výpočetní tomografie může také přispět k posouzení stratifikace rizika úmrtnosti po extrakci elektrody. Pacienti s potvrzenou infekcí CIED bez postižení kapsy na $\left[{ }^{18} \mathrm{~F}\right]$ FDG PET/CT měli nepříznivý výsledek, což naznačuje, že přítomnost endovaskulární infekce pramenící z nerozpoznaného/vzdáleného místa je spojena se špatnou prognózou (tabulka 7, obr. 3). 
Tabulka 7 - Doporučení pro zobrazovací metody při diagnostice infekcí CIED

Konsenzuální stanovisko

Trída

Kódování

stanoviska vědecké evidence

U pacientů se suspektní IE spojenou s CIED je doporučeno provedení TTE jako zobrazovací metody první volby

Každý pacient by měl mít při podezření na infekci CIED proveden snímek plic

TEE je doporučena v případě suspekce na infekci CIED s pozitivními nebo negativními hemokulturami, nezávisle na výsledku TTE před extrakcí, k vyloučení IE spojené s CIED

Opakovat TTE a/nebo TEE každých pět až sedm dní je doporučeno, i přesto že bylo vstupní vyšetření negativní, v př́ípadě trvání podezření na IE spojenou s CIED

TEE by měla být provedena u pacientů s bakteriemií $S$. aureus, pokud mají CIED

V př́padě, že jsou pozitivní hemokultury a negativní nález na TTE a TEE a trvá podezření na IE spojenou s CIED, mělo by být zváženo vyšetření ICE

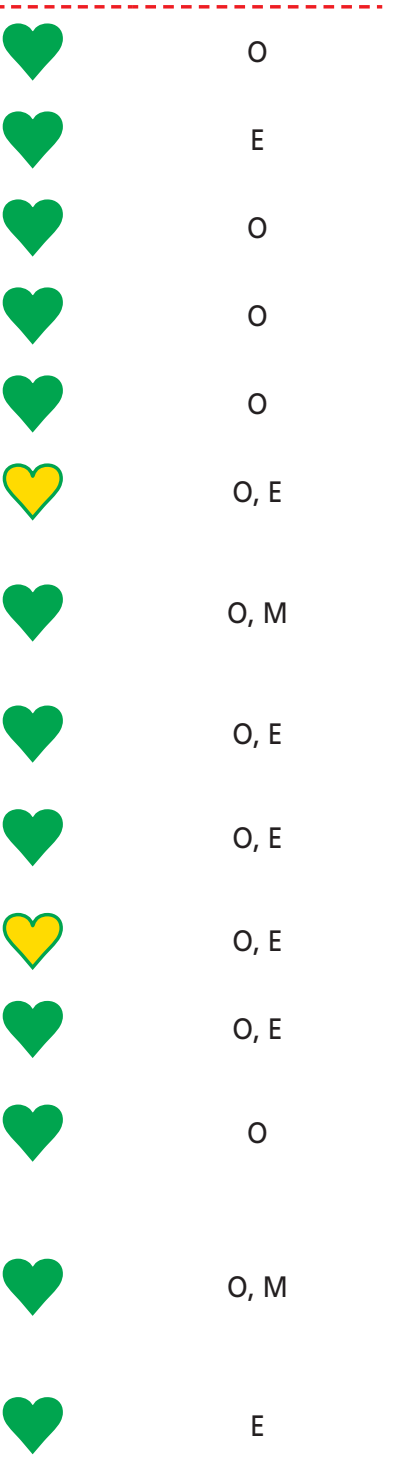

Pokud existuje podezření na IE spojenou s CIED, hemokultury jsou pozitivní a echokardiografický nález je negativní, je doporučeno provedení $\left[{ }^{18} \mathrm{~F}\right] \mathrm{FDG}$ PET/CT nebo scintigrafie značenými leukocyty nebo CT vyšetření s kontrastní látkou (pozor na interpretaci nálezů časně po implantaci)

$\mathrm{U}$ pacientů s CIED by v prípadě $S$. aureus bakteriemie mělo být provedeno $\left[{ }^{18} \mathrm{~F}\right] \mathrm{FDG}$ PET/CT vyšetření

V prípadě nejasných embolizačních lokalizací (tj. plicní embolizace) a metastatické infekce je doporučeno $k$ identifikaci zdroje provést $\left[{ }^{18} \mathrm{~F}\right] \mathrm{FDG}$ PET/CT, scintigrafii značenými leukocyty a/nebo CT vyšetření s kontrastní látkou

Mělo by být zváženo provedení [ $\left.{ }^{18} \mathrm{~F}\right]$ FDG PET/CT a scintigrafie značenými leukocyty k identifikaci brány vstupu infekce, a tím $\mathrm{k}$ prevenci recidivy IE

CT angiografie plic je doporučována u pacientů s recidivujícími zápaly plic

U pacientů s infekcí CIED a po perkutánní extrakci elektrod je před propuštěním doporučeno TEE/ TTE vyšetření k detekci př́tomnosti ponechaných fragmentů elektrod a také k evaluaci plicní hypertenze a funkce trikuspidální chlopně a pravé komory

V prípadě pokračující sepse po extrakci systému:

- je doporučeno TEE vyšetření k identifikaci reziduálního izolačního materiálu elektrod a lokálních komplikací

- [ ${ }^{18}$ F]FDG PET/CT, scintigrafie značenými leukocyty a/nebo CT vyšetření s kontrastní látkou pro lepší zhodnocení lokálního šiření infekce a také ve zbylých částech těla

Hodnocení výsledků zobrazovacích metod by mělo být provedeno multidisciplinárním týmem („tým endokarditidy“)

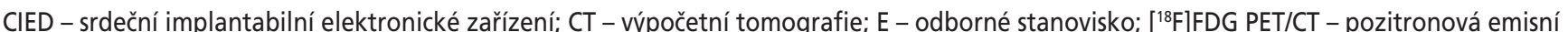
tomografie/výpočetní tomografie s podáním fluorodeoxyglukózy značené fluorem-18; IE - infekční endokarditida; M - metaanalýza; O - observační studie; TEE - transezofageální echokardiografie; TTE - transtorakální echokardiografie.

U vybraných pacientů může být užitečné provedení CT s kontrastní látkou. Přidání kontrastní látky ke standardnímu protokolu [ $\left.{ }^{18} \mathrm{~F}\right]$ FDG PET/CT vedlo ve vysoké míře k reklasifikaci z „možné” na „potvrzenou” infekční endokarditidu, což zlepšilo celkovou diagnostickou přesnost s Dukeovými kritérii nebo bez nich u řady pacientů s podezřením na plicní embolii nebo infekci CIED. CT angiografie srdce může také přidat důležité doplňující informace o cévních komplikacích, včetně mykotických aneurysmat, arteriálních embolií a septických plicních infarktů. Tyto informace se následně přidávají k diagnostickým kritériím a ovlivňují celkovou léčebnou strategii. Kromě toho může být u pacientů s rekurentní pneumonií užitečná plicní CT angiografie. Širšímu použití CT s kontrastní látkou brání škodlivý účinek kontrastních látek na funkci ledvin, zejména pokud jsou pacienti vystaveni nefrotoxické antibiotické terapii. Nedávno byl publikován rozsáhlý popis technických aspektů a interpretačních kritérií pro multimodální zobrazování.

Pro hodnocení výsledků zobrazovacích metod je doporučena multidisciplinární týmová spolupráce („tým endokarditidy") a bylo prokázáno, že významně snižuje roční úmrtnost, z 18,5 \% na 8,2 \%. Obrázek 2 ukazuje navrhovaný diagnostický algoritmus použití zobrazovacích metod u pacientů s podezřením na infekci CIED. 
Tabulka 8 - Doporučení pro odstranění zařizení a elektrod

Konsenzuální stanovisko

Trída

stanoviska

Kódování

U pacientů s potvrzenou infekcí CIED (systémovou a lokální) se doporučuje úplné odstranění

zařízení (včetně zaslepených elektrod, epikardiálních elektrod a fragmentů elektrody)

vědecké evidence

Po diagnóze infekce CIED by mělo být zařízení odstraněno bez zbytečného odkladu (nejlépe do tří dnů)

Doporučená technika pro odstranění systému zařízení je perkutánní transvenózní extrakce.

Epikardiální elektrody vyžadují chirurgické odstranění

U pacientů se systémovou infekcí a vegetacemi elektrod přibližně $>20 \mathrm{~mm}$ může být zvážena perkutánní aspirace vegetací před transvenózní extrakcí elektrod a během ní nebo alternativně Ize zvážit chirurgickou extrakci

Po vyjmutí zařízení je doporučeno pečlivé odstranění kapsy generátoru (kompletní excize fibrotické kapsuly a úplné odstranění veškerého neabsorbovatelného šicího materiálu) a následný proplach rány sterilním fyziologickým roztokem

Měla by být provedena kultivace extrahovaného CIED

Pro uzavření rány po odstranění zařízení a débridementu kapsy lze použít následující metody:

- Primární uzávěr s použitím drénu nebo bez použití drénu

- Opožděné uzavření po podtlakové léčbě rány

Úplné odstranění CIED je indikováno u bakteriemie nebo fungemie u S. aureus, CoNS,

Cutibacterium spp. a Candida spp.

U bakteriemie s alfa- nebo beta-hemolytickým Streptococcus spp. a Enterococcus spp. úplné odstranění CIED může být provedeno jako ošetření první linie nebo v případě rekurentní/ pokračující bakteriemie navzdory vhodné antibiotické terapii jako druhý krok terapie

0

O

0

0

0

Q

E

$E$

E, O

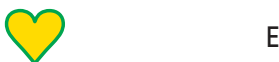

V případě bakteriemie s nepseudomonádovými/serratickými gramnegativními bakteriemi nebo pneumococci by odstranění CIED mělo být provedeno v prípadě opakující se/trvající bakteriemie navzdory vhodné antibiotické terapii, pokud není žádný jiný identifikovatelný zdroj pro opakovanou nebo pokračující infekci

U pacientů s infekční endokarditidou se doporučuje úplné odstranění CIED s definitivním spojením systému CIED s infekcí/bez tohoto spojení

Do 48-72 hodin po odstranění infikovaného CIED by měly být odebrány hemokultury

CIED - srdeční implantabilní elektronické zařízení; E - odborné stanovisko; O - observační studie.

\section{Management infekcí srdečních implantabilních elektronických zařízení (CIED): kdy, jak a kde}

\section{Extrakce srdečního implantabilního elektronického zařízení}

Klíčovým aspektem úspěšné léčby potvrzené infekce CIED je úplné odstranění všech částí systému a transvenózního hardwaru, což zahrnuje zařízení samotné, všechny elektrody (aktivní, zaslepené, epikardiální i fragmenty elektrod) a také cévní porty nebo permanentní hemodialyzační katétr. Tento koncept léčby se vztahuje na systémové i lokalizované infekce kapsy CIED. V retrospektivní studii 416 pacientů s infekcemi CIED byla antibiotická terapie bez odstranění zařízení spojena se sedminásobným zvýšením 30denní úmrtnosti (poměr rizik 6,97, 95\% Cl 1,36-35,60) v multivariační analýze. Načasování extrakce by mělo proběhnout bez zbytečného odkladu ihned po diagnóze infekce CIED (obr. 2 a 3) a měla by být provedena v centru se zkušenostmi (tabulka 8). Provedení transvenózní extrakce elektrod v průběhu prvních tří dnů po hospitalizaci vede k výrazně nižší nemocniční úmrtnosti a kratším hospitalizacím u pacientů s infekcemi CIED. Je důležité si uvědomit, že navzdory správné léčbě, zahrnující extrakci systému CIED a adekvátní antibiotickou terapii, je úmrtnost pacientů u systémové infekce výrazně vyšší než u pacientů s lokální infekcí. Na základě výsledků registru ELECTRa byla systémová infekce identifikována jako prediktor zvýšení mortality ze všech prríčin (OR 4,93,95\% Cl 2,72-8,93, $p<0,0001)$.

V prípadě potřeby extrakce zařízení je metodou první volby perkutánní transvenózní extrakce (tabulka 8), protože má v období 1 a 12 měsíců výrazně nižší počet závažných komplikací a nižší úmrtnost ve srovnání s otevřenými chirurgickými př́stupy. Tyto metody jsou preferovány dokonce $\mathrm{i} v$ prítomnosti vegetací elektrod přesahujících rozměr $10 \mathrm{~mm}$ (tabulka 8 ). Malé série případů uváděly dobré krátkodobé výsledky transvenózních extrakcí elektrod u pacientů s velkými vegetacemi navzdory vysokému procentu plicní embolie. Dlouhodobé výsledky těchto pacientů však zůstávají nejasné. U pacientů s vegetací větší než 20 mm Ize zvážit otevřenou chirurgickou extrakci. I při transezofageální echokardiografii může být obtížné odhadnout velikost vegetace. Při plánování postupu by 
se kromě velikosti měla brát $v$ úvahu drobivost vegetace (tabulka 8). Slibným konceptem u pacientů se systémovou infekcí CIED a velkými vegetacemi elektrod je perkutánní aspirace vegetací pomocí venovenózního mimotělního okruhu s in-line filtrem. Cílem této léčby je snízit zatížení při uvolnění bakteriálních vegetací a riziko embolizace infekčního materiálu do plicního oběhu, což může být zdrojem přetrvávajících septických komplikací. V př́ípadě infekcí systémů CIED s epikardiálními elektrodami se úplné odstranění těchto elektrod doporučuje jen $v$ případě jednoznačného postižení elektrod na základě individuální analýzy rizik (operativní riziko odstranění epikardiálních elektrod vs. riziko úmrtnosti související s infekcí). V případě lokalizované infekce kapsy systému CIED bez potvrzené infekce distální cásti epikardiální elektrody je vhodné ponechat distální část elektrody in situ tím, že přerušíme elektrodu z nového řezu a poté extrahujeme proximální část elektrody kapsou. Při hodnocení těchto mimořádných situací může být užitečný [ ${ }^{18}$ F]FDG PET/CT sken.

$\checkmark$ případě okultní bakteriemie nebo fungemie záleží další postup na výsledcích mikrobiologického vyšetření. Úplné odstranění CIED je indikováno u bakteriemie nebo fungemie způsobené $S$. aureus, koaguláza-negativními stafylokoky, Cutibacterium spp. a Candida spp. U bakteriemie způsobené alfa- nebo beta-hemolytickými streptokoky a Enterococcus spp. může být úplné odstranění CIED provedeno jako léčba první linie nebo jako druhý krok v případě recidivující/pokračující bakteriemie navzdory vhodné antibiotické terapii. $V$ př́padě bakteriemie $s$ nepseudomonádovými/serratickými gramnegativními bakteriemi nebo pneumokoky je nejprve namístě vhodná antibiotická terapie. $V$ prípadě rekurentní/pokračující bakteriemie by mělo být úplné odstranění CIED provedeno i v případech, kdy není nalezen žádný jiný identifikovatelný zdroj pro opakující se nebo pokračující infekci. Úplné odstranění CIED je navíc indikováno u pacientů s infekční endokarditidou i bez potvrzené infekce systému CIED.

Po odstranění zařízení a elektrod je rozhodující velice pečlivý débridement kapsy s úplným vyříznutím fibrotické kapsuly, jakož i odstranění veškerého neabsorbovatelného šicího materiálu a následný výplach rány sterilním fyziologickým roztokem. Vypláchnutí rány roztokem antibiotik neposkytuje žádnou významnou výhodu oproti výplachu fyziologickým roztokem. Uzavření rány může být provedeno inned s použitím drenáže či bez použití drenáže nebo může být odloženo s použitím podtlakové terapie a následným uzávěrem.

Pokud dojde k povrchové infekci rány brzy po implantaci, výměně zařízení nebo revizi, nemělo by být odstraněno zařízení a elektrody. Povrchové infekce jsou omezeny na kůži a podkožní tkáň bez postižení jakýchkoli částí systému CIED. Rozlišování mezi povrchovou infekcí a infekcí kapsy je klinicky složité, proto je důležité pečlivě sledovat pacienty, u nichž existuje podezření na povrchovou infekci. $U$ těchto pacientů je vhodné podávání perorální antibiotické terapie po dobu 7-10 dní.

\section{Antimikrobiální terapie včetně dlouhodobé supresivní terapie}

Rozhodující léčbou infekce CIED je včasné a úplné odstranění všech částí systému a antibiotickou terapii je třeba chápat jako doplněk $\mathrm{k}$ léčbě přidružené systémové infekce a k vyléčení zbývající infekce v nativních tkáních. Randomizované kontrolované studie vedoucí $k$ výběru antibiotik u infekce CIED chybějí a doporučení vycházejí z kohortových studií, sérií případů, znaleckých posudků a farmakologických úvah. Antibiotickou terapii ovlivňuje možnost časného odstranění zařízení, léčebné režimy se $v$ jednotlivých zemích liší také v závislosti na prevalenci MRSA, rozdílech ve stupni bakteriální rezistence na antibiotika a př́stupu ke konkrétním antibiotikům včetně novějších látek. Kombinovaná antibiotická terapie s rifampicinem zaměřeným na stafylokokovou infekci spojenou s biofilmem se nedoporučuje, pokud bude zařízení odstraněno, s výjimkou doprovodné infekce spojené s cizím tělesem, tj. endokarditida protetické chlopně, kde není možnost chirurgické náhrady. Samostatná antibiotická léčba se u infekcí CIED nedoporučuje, ale ne všichni pacienti musejí být kandidáty na odstranění zařízení. U menšího počtu pacientů byla hlášena úspěšná terapie pouze antibiotiky a ve vybraných prípadech se používá také dlouhodobá supresivní antibiotická terapie.

V tabulce 9 jsou shrnuta doporučení týkající se terapie antibiotiky včetně empirické léčby pro tři hlavní kategorie infekcí CIED, tedy povrchové infekce incize, izolované infekce kapsy zařízení a systémové infekce. Systémové infekce jsou dále rozděleny v závislosti na př́tomnosti pozitivních hemokultur a vegetací na elektrodách a/nebo chlopních.

U povrchové infekce rány se před zahájením léčby antibiotiky doporučuje odeslat stěr ke kultivaci (tabulka 9).

Pro izolované infekce kapes se po odběru hemokultur doporučuje intravenózní antibiotická léčba (tabulka 9, obr. 3). Ta by měla následně být upravena dle výsledku hemokultur, nejlépe na antibiotikum s úzkým spektrem, pokud možno beta-laktamové. Kombinovaná antibiotická terapie není nutná. Přechod na perorální léčbu po odstranění zařízení je rozumný, protože zbývající infekce se týká pouze kůže a měkkých tkání, ale evidence-based doporučení pro tento postup chybějí. Při erozi kapes s minimálním zánětem je třeba zvážit odloženou antibiotickou terapii až po odstranění zařízení a dle výsledkủ kultivace odebrané z kapsy.

$\checkmark$ prípadě infekce kapsy s pozitivní hemokulturou, ale bez vegetace na elektrodách nebo chlopních, se konečná léčba řídí doporučeními uvedenými výše, ale vzhledem k systémové infekci není vhodný přechod na perorální antibiotický režim (tabulka 9, obr. 3). Zvažována ale může být kratší doba léčby antibiotiky po extrakci zařízení.

Pro CIED endokarditidy s pozitivní hemokulturou a s vegetací na elektrodè nebo chlopni se doporučení řídí pokyny pro infekční endokarditidu (tabulka 9). Pokud jícnová echokardiografie provedená po odstranění zařízení nevykazuje známky vegetace chlopní (tj. jednalo se o izolovanou vegetaci elektrod), následné hemokultury jsou negativní, dojde ke zlepšení klinického stavu a nejsou známky plicních abscesů, trvání léčby antibiotiky dva týdny po extrakci zařízení může být dostatečné, ale celkové trvání léčby by nemělo být kratší než čtyři týdny (obr. 3).

Při bakteriemii u pacienta bez př́znaků infekce kapsy nebo echokardiografického průkazu postižení elektrody nebo chlopně se antibiotická léčba řídí obecnými doporučeními. Vzhledem $\mathrm{k}$ riziku nezjištěné infekce by měla být zvážena extrakce zařízení i v prípadě, že není prokázána 
Tabulka 9 - Mezinárodní konsenzuální doporučení pro antibiotickou terapii včetně dlouhodobé supresivní terapie

Konsenzuální stanovisko

Tríída

Kódování stanoviska vědecké evidence

\section{Povrchová infekce jizvy}

Empirická léčba:

Perorální antibiotikum pokrývající S. aureus

Flucloxacillin perorálně (jako alternativa amoxicillin-klavulanát)

Při vysoké prevalenci MRSA: trimethoprim-sulfamethoxazol,

clindamycin, doxycyclin, linezolid

Úprava dle výsledku kultivace

Flucloxacillin p.o. $1 \mathrm{~g}$ každých 6-8 $\mathrm{h}$ (amoxicillin-klavulanát standardní

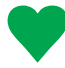

Trvání: sedm až deset dní dávkování)

Izolovaná infekce kapsy (negativní hemokultury)

Empirická léčba:

Zaměřeno na methicilin-rezistentní koaguláza-negativní stafylokoky

(CoNS) a S. aureus:

vancomycin (daptomycin je alternativa)

Při systémových symptomech:

Pro další gramnegativní pokrytí zkombinujte s cefalosporinem

3. generace (nebo beta-laktamovým antibiotikem s širším

spektrem) nebo gentamicinem

Následně úprava dle výsledku kultivace

U citlivých stafylokoků: flucloxacillin (alternativou je cefalosporin 1. generace)

Hojně bývá užívána částečně perorální léčba.

Trvání léčby po extrakci: 10-14 dní

Vancomycin: 30-60 mg/kg/d i.v. ve 2-3 dávkách (daptomycin $8-10 \mathrm{mg} / \mathrm{kg}$ i.v. $1 \times$ denně)

$\pm$

cefalosporin ve standardní dávce

nebo

gentamicin 5-7 mg/kg i.v

$1 \times$ denněa

Flucloxacillin: 8 g/d i.v. po 6 hodinách

(cefalosporin 1. generace ve standardní dávce)

Systémové infekce

Bez vegetace na elektrodách nebo chlopních \pm infekce kapsy

Empirická léčba: (zaměřená na methicilin-rezistentní stafylokoky a gramnegativní bakterie):

vancomycin (daptomycin jako alternativa)

+ cefalosporin 3. generace (nebo beta-laktamové antibiotikum

s širším spektrem) nebo gentamicin

Následně úprava dle výsledku kultivace

U citlivých stafylokoků: flucloxacillin (alternativou je cefalosporin

1. generace)

Trvání léčby po extrakci: čtyři týdny (dva týdny, pokud jsou

negativní hemokultury, viz text)

\section{Systémové infekce:}

CIED endokarditida s vegetací na elektrodě a/nebo chlopni \pm embolie

Empirická léčba:

vancomycin (daptomycin je alternativa)

+ cefalosporin 3. generace (nebo širokospektré beta-laktamové antibiotikum) nebo gentamicin

Následně úprava dle výsledku kultivace podle Doporučení ESC pro

léčbu endokarditidy z roku 2015

$U$ protetické chlopně a stafylokokové infekce: rifampicin doplnit po 5-7 dnech

Trvání léčby infekční endokarditidy nativní chlopně: čtyři týdny po extrakci, pro endokarditidu protetické chlopně: (čtyři až) šest týdnů,

pro izolovanou vegetaci elektrody: dva týdny po extrakci mohou být postačující (celková doba léčby

čtyři týdny) - kromě infekce $S$. aureus, viz text

Bakteriemie u pacienta s CIED bez známek infekce kapsy nebo echokardiografického důkazu postižení elektrody nebo chlopně

Podle pokynů pro specifickou léčbu konkrétních patogenů, viz text
Vancomycin; $30-60 \mathrm{mg} / \mathrm{kg} / \mathrm{d}$ i.v. ve 2-3 dávkách (daptomycin 8-10 mg/kg 1× denně)

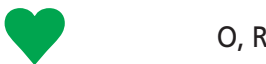

+ cefalosporin ve standardní dávce nebo

gentamicin 5-7 mg/kg i.v.

$1 \times$ denněa

Rifampicin: 900-1200 mg/denně perorálně (nebo i.v.) ve dvou dávkách
O, R

O, R

$O, R$

O, R 
Tabulka 9 - Mezinárodní konsenzuální doporučení pro antibiotickou terapii včetně dlouhodobé supresivní terapie

Konsenzuální stanovisko

Trí́da stanoviska

Kódování vědecké evidence

Pokus o záchrannou terapii a dlouhodobá supresivní terapie

I.v. antibiotika jako u endokarditidy protetické chlopně po dobu čtyř až šesti týdnů, zastavit antibiotickou léčbu za pečlivého sledování nebo pokračovat v individuální dlouhodobé supresivní perorální terapii, viz text

E - odborné stanovisko; i.v. - intravenózní; M - metaanalýza; MRSA - methicilin-rezistentní Staphylococcus aureus; O - observační studie, p.o-perorálně, $\mathrm{R}$ - randomizovaná studie.

a Pro pacienty s normální funkcí ledvin.

vegetace, a to při infekci specifickými patogeny nebo při recidivující bakteriemii z nejasného zdroje, chybějí však randomizované studie. Přidání rifampicinu do terapie se nedoporučuje $u$ pacientů $s$ bakteriiemií způsobenou $S$. aureus, ale lze jej zvážit v prítomnosti neodstranitelného cizího tělesa. Odstranění CIED je obecně doporučeno při bakteriemii vyvolané $S$. aureus, koaguláza-negativními stafylokoky, Cutibacterium spp. a Candida spp. Při průkazu viridujících a beta-hemolytických streptokoků nebo enterokoků by se kromě odstranění zařízení mělo uvažovat i o prodloužení intravenózní antibiotické terapie (čtyři týdny). Přestože jsou gramnegativní bakterie schopné sekundárního osídlení zařízení, souběžná infekce CIED je neobvyklá, a proto u infekce nepseudomonádovými/ serratickými gramnegativními bakteriemi nebo pneumokoky odstranění zařízení obecně není nutné.

Pokud kompletní odstranění zařizené není možné, je vhodné jako pokus o záchrannou terapii použít dlouhodobou supresivní terapii i.v. antibiotikem podle doporučení pro endokarditidu protetické chlopně, a to po dobu čtyř až šesti týdnů (tabulka 9, obr. 3). Pokud je plánována perorální terapie (tabulka 9), měl by být vybrán prípravek dle výsledků hemokultur, avšak tento postup nemá podklad v medicíně založené na důkazech. U stafylokoků citlivých na methicilin je některými odborníky považován za možnost volby perorální flucloxacillin, jiní jej ale nepoužívají vzhledem k jeho nízké biologické dostupnosti po perorálním podání. V prípadě methicilin-rezistentního $S$. aureus nebo koaguláza-negativních stafylokoků je alternativou perorální podání trimethoprimu-sulfamethoxazolu, clindamycinu nebo doxycyclinu (pokud jsou citlivé). Linezolid není pro dlouhodobé podávání vhodný. Rifampicin a kyselina fusidová nejsou vhodné jako monoterapie a kombinace antibiotik není pro dlouhodobou supresivní terapii obecně príliš preferována. Trvání léčby musí být př́sně individualizováno.

Preventivní strategie po implantaci srdečních elektronických zarízzení, implantace po extrakci a implantace nových alternativních zařízení

\section{Preventivní strategie po implantaci srdečních elektronických zařízení}

Protože odstranění nebo extrakce CIED jsou obvykle vyžadovány $v$ případě infekce, je prevence infekce klíčovým cílem. Zatímco primární preventivní opatření, včetně profylaktické antibiotické terapie, vhodných opatření pro kontrolu infekce a pečlivá chirurgická technika, jsou dobře zavedena a důrazně doporučena, údaje podporující přínos sekundární profylaxe jsou relativně vzácné a kontroverzní. Pro včasnou identifikaci infekčních komplikací souvisejících s CIED je od počátku nutné klinické sledování a podrobné vzdělávací programy pro pacienty, včetně videokonzultací pro prohlídky ran. Krátká doba léčby může zabránit progresi, ale může také maskovat infekci kapsy, oddálit odpovídající léčbu nebo vystavit pacienta zbytečné lékařské terapii.

V současné době neexistuje žádný přesvědčivý důkaz, že mikroorganismy spojené s invazivními lékařskými postupy způsobují infekci nevalvulárních vaskulárních zarrízení kdykoli po implantaci (tabulka 10). Antibiotická profylaxe se proto u pacientů s CIED rutinně nedoporučuje, at' už podstupují výkony stomatologické, respirační, gastrointestinální, genitourinární, nebo kardiální. Sekundární profylaxe se doporučuje pouze u pacientů, kteří se podrobí incizi a drenáži infekce na jiných místech těla nebo výměně infikovaného zařízení.

\section{Implantace nového zařízení po extrakci}

Všechny potvrzené infekce CIED, systémové nebo lokalizované, vyžadují úplné odstranění hardwaru a žádná část odebraného CIED by neměla být znovu implantována. To platí také pro žilní sheath používaný pro perkutánní odstranění, který by neměl být použit pro implantaci nového systému. Pokud je to možné, měly by se také vyměnit centrální a periferní žilní katétry a jakékoli jiné vyjímatelné katétry.

Indikace pro reimplantaci by měla být po odstranění CIED vždy znovu vyhodnocena. Optimálním výběrem může být jiný typ zařízení než předchozí nebo již v době extrakce chybí indikace $k$ implantaci úplně. Neexistují žádné randomizované studie, které by doporučily vhodné načasování reimplantace, a proto musí být toto rozhodnutí individualizováno. Opakovaná implantace by měla pokud možno být odložena do odeznění příznaků místní a systémové infekce a dokud nebudou hemokultury negativní po dobu alespoň 72 hodin po extrakci (tabulka 10). U pacientů dependentních na stimulaci se zdá být rozumné použít dočasnou stimulaci (tabulka 10), dokud příznaky a známky systémové infekce nezmizejí, poté je možné implantovat nové permanentní zařízení. Nejlepší strategií k bezpečnému oddálení reimplantace se 
Tabulka 10 - Doporučení pro preventivní strategie po implantaci zařizení a pro nové reimplantace včetně alternativních nových zařizení

Konsenzuální stanovisko

Trída

stanoviska

Po extrakci zařízení je doporučeno opětovné posouzení indikace pro reimplantaci

V případě lokální nebo systémové infekce je vhodné reimplantaci zrušit nebo odložit do odeznění známek infekce

U pacientů dependentních na stimulaci, vyžadujících vhodnou antibiotickou léčbu Ize před reimplantací zvážit dočasnou stimulaci ipsilaterálně fixovanou elektrodou

Preferovaná přístupová místa pro náhradní zařízení jsou kontralaterální strana, femorální žíla nebo epikardiální př́stup

Dočasná stimulace u pacientů, kteří nejsou dependentní na stimulaci

Implantace náhradního zařízení ipsilaterálně k místu extrakce

Alternativní nová zařízení jako LPM a S-ICD mohou být zvažována u vybraných pacientů s vysokým infekčním rizikem nebo u pacientů, u nichž jsou tato zařízení po infekci CIED zvažována jako lepší možnost
Kódování

vědecké

evidence

$\mathrm{O}$

0

0

E, O

O

$\mathrm{E}$

0

CIED - srdeční implantabilní elektronické zařízení; E - odborné stanovisko; LPM - bezelektrodový kardiostimulátor (leadless pacemaker); O - observační studie; S-ICD - subkutánní defibrilátor.

jeví použití elektrody s aktivní fixací implantované přes jinou žílu, než kudy byla původní elektroda extrahována (ale na stejné straně těla), a připojení k externalizovanému kardiostimulátoru. Tím je zachována kontralaterální neinfikovaná strana pro implantaci permanentního zařízení. Epikardiální umístění elektrody se používá po celá desetiletí jako jediná spolehlivá strategie pro pacienty s velmi vysokým rizikem reinfekce.

\section{Alternativní nová zařízení}

Bezelektrodový kardiostimulátor (leadless pacemaker, LPM) a subkutánní ICD jsou vynikající alternativy k tradičním CIED. V současné době byly vyvinuty dva samostatné komorové kardiostimulátory implantované cestou femorálního př́istupu: Micra ${ }^{\mathrm{TM}}$ Transcatheter Pacing System (TPS; Medtronic, Minneapolis, MN, USA) a Nanostim TM Leadless Cardiac Pacemaker (LCP; St. Jude Medical, Sylmar, St. CA, USA), ačkoli pro klinické použití je v současné době k dispozici pouze první z nich. Je stimulována pravá komora s použitím rate-responsive technologie a mưže představovat rozumné alternativní řešení, pokud je správně indikován. V krátkodobém až střednědobém sledování nedošlo k žádné infekci. U vybraných vysoce rizikových pacientů se riziko infekce LPM zdá nízké. Užití prrístroje se také jeví jako bezpečné a realizovatelné u pacientů s již existující infekcí CIED po extrakci infikovaných elektrod. Podobně také u S-ICD se v mnoha klinických studiích ukázalo, že je bezpečné a účinné při detekci, diskriminaci a terminaci potenciálně život ohrožujících komorových arytmií, i když není schopna dodávat antitachykardický pacing (ATP) a může poskytovat pouze komorovou stimulaci s frekvencí 50/min po dobu 30 s po výboji. U vybraných pacientů bez nutnosti stimulace, ATP nebo CRT došlo při implantaci S-ICD k významnému snížení rizika nových infekcí, přičemž byl zajištěn účinný a bezpečný defibrilační systém. I když nenabízejí úplnou ochranu před infekcí, jejich odstranění je mnohem jednodušší a nejčastěji nevede k život ohrožující systémové infekci. Zatímco data z randomizovaných studií stále přicházejí, data od 985 pacientů zapsaných do evropského registru EFFORTLESS potvrzují výskyt infekce (vyžadující odstranění zařízení) ve $2,4 \%$ během tří let sledování. V blízké budoucnosti se očekává, že budou mít LPM a S-ICD (Boston Scientific) integrovanou bezdrátovou komunikaci mezi zařízeními za účelem koordinace stimulační a antitachykardické terapie. Pro pacienty s vysokým rizikem náhlé srdeční smrti bez potřeby stimulace lze krátkodobě použít nositelný defibrilátor (LifeVest, Zoll) jako řešení do reimplantace.

\section{Prognóza, výsledky a komplikace infekcí srdečních implantabilních elektronických zařízení}

Infekce srdečních implantabilních elektronických zařízení má nemocniční nebo 30denní úmrtnost 5-8 \% včetně úmrtnosti způsobené extrakcí elektrod, obvykle hlášenou jako 0,5 \%, což je však hlavně spojeno se komplikacemi probíhající sepse. Úmrtnost je vyšší u pacientů s významnými komorbiditami (např. srdeční selhání, renální insuficience, užívání kortikosteroidů), u pacientů s endokarditidou asociovanou s CIED spíše než při infekci kapsy a u pacientů, kteří nepodstoupí úplné odstranění systému. Nemocniční morbidita zahrnuje také komplikace extrakcí elektrod, obvykle uváděné jako $2-3 \%$, včetně emergentní torakotomie při perforaci, arteriovenózní píštěle a poškození trikuspidální chlopně; dále septické plicní embolie (1\%), arytmie a pokračující sepsi. Po odstranění zařízení mohou komplikace vzniknout i po implantaci nového zařízení, zejména opakující se infekce, ačkoli jsou vzácné za předpokladu adekvátní antibiotické terapie a načasování nové implantace. Pacienti, kteří nepodstoupili úplné odstranění systému, zejména proto, že jsou považováni za příliš křehké, 
mají velmi vysokou nemocniční úmrtnost, která pokračuje i měsíce po propuštění. Prodlení při plánování extrakce také vede $\mathrm{k}$ horší prognóze. Dlouhodobá úmrtnost u pacientů po infekci CIED je až 1,5-2,4krát vyšší než úmrtnost neinfikovaných pacientů, což je 6-15 \% za jeden rok a 14$33 \%$ za tři roky, přičemž rozsah odhadů odráží věk a komorbidity studovaných pacientů. I po úpravě podle komorbiditních faktorů mají pacienti s infekční endokarditidou a ženy vyšší dlouhodobou mortalitu než muži. Př́tomnost selhání ledvin v konečném stadiu dává obzvláště špatnou prognózu. Není však jasné, zda vyšší dlouhodobá úmrtnost je způsobena samotnou infekcí CIED nebo prítomností negativních prognostických faktorů u pacientů, u nichž se vyvinula infekce CIED (např. srdeční selhání, renální insuficience, koagulopatie, užívání kortikosteroidů, diabetes), nebo zda špatný výsledek odráží nedostačující terapeutický postup. Existují náznaky, že pacienti, kteří byli úspěšně léčeni („vyléčeni“) s úplným odstraněním systému a plnou antibiotickou kúrou, mohou mít podobnou prognózu jako pacienti, kteří nikdy nebyli infikováni.

\section{Zvláštní pokyny k prevenci infekcí souvisejících se zařízeními (starší pacienti, děti, dospělí s vrozenou srdeční vadou)}

Některé populace pacientů představují další rizika a vyžadují hlubší úvahy pro prevenci infekce. Jednou z těchto populací jsou starší pacienti, kteří potřebují kardiostimulátor nebo ICD. V několika studiích není věk sám o sobě nezávislým prediktorem infekce, pokud je adjustován k dalším komorbiditám, jako je diabetes, selhání ledvin, srdeční selhání, malignita a onemocnění plic. Křehkost, která je běžná u starších lidí, je spojena s horšími kardiovaskulárními následky. Pacienti s elektronickým implantabilním srdečním zařízením se sníženou pohyblivostí a sníženou aktivitou budou pravděpodobně celkově křehčí. Ve studii s téměř 84000 pacienty sledovanými v National Cardiovascular Device Registry-ICD (NCDR-ICD) kombinace křehkosti s dalšími známými rizikovými faktory pro infekce CIED predikovaly vyšší úmrtnost. Starší lidé jsou často vystaveni většímu riziku eroze zařízení v důsledku ztráty podkožní tkáně a svalové hmoty. Použití subpektorálního uložení přistroje může u vhodných pacientů poskytnout lepší ochranu před erozí. Existuje několik chirurgických přístupů k subpektorálnímu prostoru a implantující lékaři by s nimi měli být obeznámeni. Stejně jako u všech pacientů je důležitý pečlivý př́stup $\mathrm{k}$ hemostáze, protože hematom je konzistentním rizikovým faktorem infekce.

Mladší věk bývá také spojen $\mathrm{s}$ vyšším rizikem infekce CIED. Ve studii 46299 pacientů zapsaných do Dánského registru kardiostimulátorů bylo 2499 (5 \%) pacientů mladších 20 let. $V$ multivariační analýze bylo zjištěno, že věk do 20 let přináší o 40 \% vyšší riziko infekce (HR 1,41,95\% CI $0,83-2,38)$. Vyšší riziko infekcí může být způsobeno celkovým počtem a složitostí postupư, které souvisejí se zařízeními a kterým je mladý člověk v průběhu svého života vystaven. Kolonizace kapsy může vést $k$ vyššímu počtu infekcí způsobených následnou výměnou generátoru. Výkony jako revize nebo náhrada elektrod mají téměř dvakrát vyšší počet komplikací než de novo implantace. $V$ jedné studii 497 dětí, které dostávaly kardiostimulátory po dobu 20 let, se střední dobou sledování šest let dosahovala míra selhání elektrody $15 \%$, k němuž došlo u $23 \%$ pacientů. U více než čtvrtiny (28 \%) pacientů došlo k opakovanému selhání elektrod. Riziko selhání elektrody bylo spojeno s věkem < 12 let při implantaci, vrozenou srdeční vadou (VSV) a umístěním elektrody epikardiálně. Hlášená míra infekce po nahrazení elektrody byla v této studii $1,9 \%$.

Údaje od NCDR-ICD zaznamenávají nízké $(0,2 \%)$ míry akutní infekce u dospělých s vrozenými srdečními chorobami. Stejně jako u dospělých, většina infekcí se u dětských pacientů a u pacientů s VSV manifestuje až při dlouhodobém sledování a zdá se být ve stejném rozsahu jako u dospělých (1-5 \% závažných infekcí). $V$ jedné retrospektivní studii registru 443 dětských pacientů S ICD nebo VSV byla 30denní a delší než 30denní kumulativní míra infekce 4,9\%. Zatímco extrakce elektrody má u pediatrické populace a populace $s$ VSV vysokou úspěšnost, při endokarditidě související s CIED a nutnosti úplné extrakce systémového zařízení mohou být důsledky velmi závažné.

Přístup $\mathrm{k}$ implantaci zařízení u dětí a pacientů $\mathrm{s}$ VSV představuje zvláštní výzvu. Vzhledem k malé velikosti, abnormální anatomii a omezenému venóznímu prístupu mohou být vyžadovány neobvyklé chirurgické př́istupy. U velmi mladých pacientů se používají epikardiální elektrody a submuskulární umístění přístroje v břišní kapse, defibrilační elektrody jsou uloženy v posterolaterálním perikardiálním prostoru. Jak děti rostou, může dojít $\mathrm{k}$ přechodu na transvenózní systémy - kardiostimulátor (PM) a ICD, pokud je k dispozici žilní přístup. Submuskulární (subpektorální) přistup pro umístění generátoru býval upřednostňován kvůli menším rozměrưm a/nebo kosmetickým důvodům. Bez ohledu na konkrétní přístup čelí mladí pediatričtí pacienti, pacienti s VSV a dospělí s VSV celoživotním revizím systému zařízení, což často vede $\mathrm{k}$ nutnosti alternativních přístupů. Alternativní přístup pro starší děti, které potřebují ICD, je S-ICD. Nepřítomnost transvenózních elektrod může snížit komplikace související se zařízením včetně infekce. Zpráva o souhrnných údajích z registru EFFORTLESS $v$ kombinaci s pacienty zařazenými do studie US FDA IDE ukázala, že u 19 pacientů s VSV (ve věku 12-65 let) nedošlo k infekcím ve srovnání s 1,5 \% systémových infekcí u zbývajících 846 nemocných. Celkové komplikace byly podobné $(10,5 \%$, respektive $9,6 \%)$ během dvouletého sledování. Ve zprávě Alliance for Adult Research in Congenital Cardiology dostalo 21 pacientů ze sedmi center S-ICD. Po 14 měsících sledování byla identifikována jediná infekce, která nevyžadovala odstranění zařízení. Také několik dalších zpráv ukázalo př́iznivý výsledek při použití S-ICD u těchto pacientů. Kardiostimulátory, které jsou programovány k bipolární stimulaci, jsou se systémem S-ICD kompatibilní a tato kombinace je u pacientů s vrozenou srdeční vadou používána. Doporučení pro prevenci infekcí spojených s implantací zařízení u starších pacientů, dětských pacientů a dospělých pacientů s VSV jsou uvedena v tabulce 11.

\section{Minimální požadavky kvality týkající se center, počtu výkonů a zkušenosti operatérů}

Údaje o tom, jak spolu souvisí velikost centra, zkušenost, počet operatérů a četnost infekcí CIED, jsou nedostaču- 
Tabulka 11 - Doporučení pro prevenci infekci spojených s implantací zařizení u starších pacientů, dětských pacientů a dospělých s vrozenou srdeční vadou

Implantující lékaři by si měli být vědomi vyšších rizik infekce CIED u křehkých a starších pacientů; u vybraných starších pacientů s menším množstvím subkutánní tkáně se doporučuje subpektorální pozice př́istrojů jako prevence dekubitu kapsy

Implantující lékaři by měli mít zkušenosti s vícečetnými a alternativními chirurgickými zákroky prováděnými u pacientů pediatrických, s VSV a dospělých pacientů s VSV, u kterých je vyšší riziko infekce CIED v důsledku vícečetných zásahů, přidávání elektrod, revizí a upgradu systému

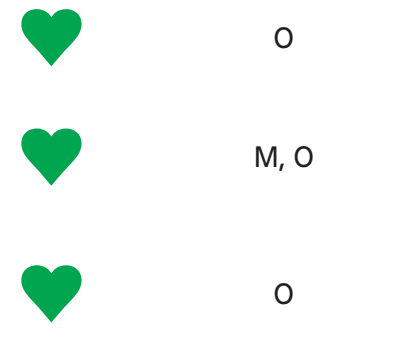

Výhradní S-ICD by měl být považován za alternativu k transvenóznímu nebo epikardiálnímu přístupu u starších dětí, pacientů s VSV a osob s omezeným nebo žádným žilním přístupem; pacienti s indikací bradykardie, pacienti vyžadující antitachykardickou stimulaci nebo srdeční resynchronizační terapii nejsou vhodnými kandidáty

CIED - srdeční implantabilní elektronické zařízení; E - odborné stanovisko; O - observační studie; S-ICD - subkutánní defibrilátor; VSV - vrozená srdeční vada.

jící a různorodé. Některé studie sahají do období před antibiotiky, všechny mají charakter pozorování, a výběr prediktorů, statistických úprav a definice infekcí CIED se velmi liší, stejně jako doba sledování. Doporučení ohledně center a zkušenosti operatérů jsou pouze přibližná, na základě observačních dat a odborného konsenzu.

Pro každý chirurgický zákrok existuje křivka učení, během níž se častěji očekávají komplikace. Při implantaci kardiostimulátorů byla zkušenost operátora $s$ méně než 100 procedur spojena s vyšším rizikem infekce v období před profylaktickými antibiotiky. Méně než 100 procedur na operatéra bylo také spojeno s vyšším rizikem jakékoli komplikace. Hematom kapsy, o kterém je známo, že má souvislost s vyšším rizikem infekce, byl častější u pacientů, jimž zařízení implantoval operatér s méně než 100 provedenými procedurami a hematom vyžadující revizi byl častější u operatéra, který provedl méně než 50 procedur. Na základě těchto zpráv se zdá rozumné doporučit pečlivý dohled nad operatéry s méně než přibližně 100 provedenými procedurami.

Několik velkých observačních studií vypočítalo riziko komplikací podle úrovně zkušeností operatéra. U implantací ICD byl počet $<29$ procedur na operatéra za rok spojen s upraveným poměrem pravděpodobnosti infekce $2,47(95 \% \mathrm{Cl} 1,18-5,17)$ ve srovnání se zkušenějšími operatéry. Zkušenější operatéři také měli za sebou větší počet implantací kardiostimulátorů. Poukázáno na jakýkoli typ komplikací, méně než 60 provedených procedur za rok bylo u operatéra spojeno s výrazně zvýšeným rizikem komplikací (HR 10,4 [1,32-82,14]) dle údajů z Ontarijské databáze ICD. Pro implantace kardiostimulátorů bylo více než 40 provedených procedur operatérem za rok spojeno s menším počtem komplikací. Z dánské celostátní kohortové studie procedur CIED vyplývá, že objem výkonů méně než 50 procedur ročně byl spojen $s$ adjustovaným poměrem rizik jakékoli komplikace 1,9 $(1,4-2,6)$ a vyšším rizikem infekce CIED $(1,7 \%$ vs. $0,5 \%, p=0,02)$. Proto se doporučuje minimální roční počet provedených procedur CIED na operatéra přibližně 50 .

Pro zkušenost implantačních center jsou data ještě méně jednotná. $U$ center $s$ nižším počtem implantací (< 250 za rok) bylo hlášeno vyšší riziko infekce při výměnách př́strojů. V historických datech z Dánského regist- ru kardiostimulátorů nebyl velký rozdíl v počtu infekcí kardiostimulátorů mezi univerzitními centry s velkým počtem výkonů a centry $s$ nižším počtem procedur (<200 procedur za rok). Z prospektivní dánské celostátní kohorty měla centra s objemem implantací nad $750 \mathrm{za}$ rok nejnižší riziko jakýchkoli komplikací, zatímco počet infekcí se mezi různě velkými centry nelišil. Nejmenší centra v této analýze však měla do 249 implantací ročně. V nizozemském registru FOLLOWPACE, který zahrnuje i centra se středními ročními počty od 53 do 220 procedur, nebyla pozorována žádná souvislost mezi velikostí centra a rizikem jakékoli komplikace, zatímco velká německá národní analýza jasně ukázala nepřímou úměru mezi rizikem jakýchkoli komplikací chirurgického výkonu a velikostí centra. Proto každé konkrétní doporučení pro minimální objem centra bude založeno na arbitrážním a konsenzuálním základě. Dá se však říci, že centrum potřebuje minimálně dva implantující (tabulka 11), z nichž každý provádí nejméně 50-60 procedur ročně. Aby se mohlo stát centrum i školicím pracovištěm, doporučuje se minimální počet 150 procedur ročně. Doporučení o minimálních požadavcích na kvalitu týkající se center, zkušeností a počtu operatérů jsou uvedena v tabulce 12 . Každé středisko by mělo monitorovat počet infekcí a zaznamenávat jej do databáze.

\section{Ekonomický pohled na infekce srdečních implantabilních elektronických zařízení a strategie ke snížení nákladů}

Incidence infekcí CIED roste rychleji ve srovnání s mírou implantací zařízení. To má důležité důsledky pro systémy zdravotní péče s ohledem na vynaložené náklady na zdravotní péči, které souvisejí s hospitalizací obvykle dva až čtyři týdny, s širokým využitím antibiotik a potřebou postupů pro odstranění zařízení a extrakci elektrod, jakož i pro reimplantaci CIED. Odhady nákladů na infekce CIED jsou omezené, vykazované hodnoty 20 623-23 234 eur ve Francii, 36931 eur (f 30 958) ve Spojeném království a hodnoty v rozmezí od 15516 eur do 337886 eur (16 651 až 362606 USD) v USA, přičemž široký rozsah byl dán různou intenzitou a komplexností léčby. Pro interpretaci 
Tabulka 12 - Doporučení týkající se minimálních požadavků na počet výkonů a operatérů v centrech pro srdeční implantabilní elektrická zařizení (CIED)

Konsezuální stanovisko

Třída

Kódování

stanoviska

vědecké evidence

Operatéři s méně než přibližně 100 provedenými výkony CIED by měli pracovat pod přísným

dohledem zkušenějších operatérů

$\mathrm{O}, \mathrm{E}$

Roční minimální doporučený počet výkonů CIED je přibližně 50 na jednoho operatéra, toto je

doporučeno pro všechny operatéry

$\mathrm{O}, \mathrm{E}$

CIED - srdeční implantabilní elektronické zařízení; E - odborné stanovisko; O - observační studie.

Tabulka 13 - Guidelines publikované různými společnostmi o řízení srdeční implantovatelné elektroniky

$\begin{array}{ll}\text { Obsah guidelines } & \text { Doporučení } \\ \text { Transoezofageální } & \text { TEE by měla být použita pro } \\ \text { echokardiografie } & \begin{array}{l}\text { diagnostiku, protože má vy̌̌śí citlivost } \\ \text { pro stanovení intravaskulární infekce } \\ \text { související s CIED než TTE }\end{array}\end{array}$

\section{$\left[{ }^{18}\right.$ F]FDG PET/CT}

nebo

scintigrafie značenými

leukocyty

Hemokultury

Tkáň kapsy generátoru/ elektroda

Tkáň kapsy generátoru/ elektroda

Radiografie

CT angiografie plic $s$ kontrastní látkou nebo bez kontrastní látky

\section{Léčba - přístup k CIED v rámci infektu}

Zánět časně po implantaci

Izolovaná infekce/dekubitus kapsy

Infekce elektrody CIED

Infekční endokarditida CIED

Okultní bakteriemie

Reimplantace zařízení

Reimplantace zařízení
Při povrchovém nebo časném zánětu může být CIED zpočátku ponecháno in situ

CIED musí být zcela odstraněno do dvou týdnů od diagnózy

$\left[{ }^{18} \mathrm{~F}\right]$ FDG PET/CT nebo scintigrafie značenými leukocyty by měly být použity jako doplňkový diagnostický nástroj

Hemokultury by měly být odebrány 48-72 h po extrakci infikovaného CIED

Perkutánní aspirace z kapsy generátoru by neměla být prováděna

Tkáň z místa kapsy by měla být vyříznuta a poslána na kultivaci

Při podezření na infekci CIED by měl být proveden rentgen hrudníku

CT angiografie plic s kontrastní látkou nebo bez kontrastní látky by měla být zvážena při podezření na infekci CIED a nevýtěžné echokardiografii

Při infekci elektrody CIED musí být odstraněn celý systém zařízení

U infekční endokarditidy CIED je povinné kompletní odstranění zařízení

Při okultní bakteriemii se doporučuje úplné odstranění zařízení

Transvenózní implantace nové elektrody by měla být pokud možno odložena, aby tím umožnila několik dní nebo týdnů antibiotické terapie

Implantace nového zařízení by neměla proběhnout na shodné straně jako extrakce; preferované lokalizace jsou kontralaterální strana, ilická žíla nebo epikardiální přistup

\begin{tabular}{llllll} 
AHA & BHRS & ESC & AHA & HRS & EHRA \\
2010 & 2015 & 2015 & 2015 & 2017 & $2019^{\mathrm{a}}$ \\
\hdashline & $\checkmark$ & $\checkmark$ & $\checkmark$ & $\checkmark$ & 7
\end{tabular}

Jen
v rámci
výzkumu

NA

7

$\begin{array}{lccccc}\text { NA } & \checkmark & \text { NA } & \text { NA } & \text { NA } & 6 \\ \checkmark & \text { NA } & \text { NA } & \text { NA } & \text { NA } & 6 \\ \text { NA } & \checkmark & \text { NA } & \text { NA } & \text { NA } & 6 \\ \text { NA } & \checkmark & \text { NA } & \text { NA } & \text { NA } & 7 \\ & & & & & \\ \text { NA } & \checkmark & \text { NA } & \text { NA } & \text { NA } & 7\end{array}$

$\begin{array}{llllll}\checkmark & \checkmark & \text { NA } & \text { NA } & \text { NA } & 8 \\ \checkmark & \checkmark & \text { NA } & \text { NA } & \text { NA } & 8 \\ \checkmark & \checkmark & \text { NA } & \text { NA } & \checkmark & 8 \\ \checkmark & \checkmark & \checkmark & \checkmark & \checkmark & 8 \\ \checkmark & \text { NA } & \text { NA } & \text { NA } & \checkmark & 8 \\ \checkmark & \checkmark & \text { NA } & \checkmark & 10 \\ & & & & \\ & & & & \\ & & & & \end{array}$


Tabulka 13 - Guidelines publikované různými společnostmi o řízení srdeční implantovatelné elektroniky

\begin{tabular}{|c|c|c|c|c|c|c|c|}
\hline Obsah guidelines & Doporučení & $\begin{array}{l}\text { AHA } \\
2010\end{array}$ & $\begin{array}{l}\text { BHRS } \\
2015\end{array}$ & $\begin{array}{l}\text { ESC } \\
2015\end{array}$ & $\begin{array}{l}\text { AHA } \\
2015\end{array}$ & $\begin{array}{l}\text { HRS } \\
2017\end{array}$ & $\begin{array}{l}\text { EHRA } \\
2019^{\mathrm{a}}\end{array}$ \\
\hline \multicolumn{8}{|c|}{ Léčba - strategie antibiotické léčby } \\
\hline Časný zánět po implantaci & $\begin{array}{l}\text { Při časném zánětu po implantaci by } \\
\text { použití antibiotické terapie mělo být } \\
\text { posuzováno př́pad od případu }\end{array}$ & NA & $\checkmark$ & NA & NA & NA & 9 \\
\hline $\begin{array}{l}\text { Nekomplikovaná infekce } \\
\text { kapsy }\end{array}$ & $\begin{array}{l}\text { U nekomplikované infekce kapsy } \\
\text { Ize použít empirickou antibiotickou } \\
\text { terapii }\end{array}$ & NA & $\checkmark$ & NA & NA & NA & 9 \\
\hline Komplikovaná infekce kapsy & $\begin{array}{l}\text { Pro infekci v místě kapsy by délka } \\
\text { antibiotické terapie měla být 10-14 } \\
\text { dní po odstranění CIED }\end{array}$ & $\checkmark$ & NA & NA & NA & NA & 9 \\
\hline Komplikovaná infekce kapsy & $\begin{array}{l}\text { Možnosti a trvání léčby antibiotiky } \\
\text { závisejí na echokardiografických } \\
\text { nálezech; pokud není zahrnuta } \\
\text { žádná nativní chlopeň, Ize léčit jako } \\
\text { nekomplikovanou infekci kapsy } \\
\text { generátoru }\end{array}$ & NA & $\checkmark$ & NA & NA & NA & 9 \\
\hline Infekce elektrody CIED & $\begin{array}{l}\text { Délka antibiotické terapie by měla být } \\
\text { alespoň } 14 \text { dní po odstranění CIED pro } \\
\text { infekce krevního řečiště }\end{array}$ & $\checkmark$ & NA & NA & NA & NA & 9 \\
\hline Infekční endokarditida CIED & $\begin{array}{l}\text { U komplikovaných infekcí by trvání } \\
\text { antibiotické terapie mělo být po dobu } \\
\text { nejméně 4-6 týdnů }\end{array}$ & $\checkmark$ & $\checkmark$ & NA & $\checkmark$ & NA & 9 \\
\hline Antibiotická profylaxe & $\begin{array}{l}\text { Před implantací CIED by měla být } \\
\text { použita systémová antibiotická } \\
\text { profylaxe }\end{array}$ & $\checkmark$ & $\checkmark$ & NA & NA & NA & 4 \\
\hline Tým/vyšší pracoviště & $\begin{array}{l}\text { Komplikovaná infekční endokarditida } \\
\text { by měla být včas předána a řešena } \\
\text { v referenčním centru s možností } \\
\text { okamžitého chirurgického zákroku } \\
\text { („tým endokarditidy") }\end{array}$ & NA & NA & $\checkmark$ & NA & NA & 7 \\
\hline
\end{tabular}

CIED - srdeční implantabilní elektronické zařízení; [ $\left.{ }^{18} \mathrm{~F}\right] \mathrm{FDG}$ PET/CT - pozitronová emisní tomografie/výpočetní tomografie s podáním fluorodeoxyglukózy značené fluorem-18; NA - není k dispozici; TEE - transezofageální echokardiografie; TTE - transtorakální echokardiografie; $\checkmark$-schválené doporučení.

a Číslo odkazuje na tabulku doporučení v tomto dokumentu, kde byl konkrétní předmět řešen.

těchto odhadů je třeba si uvědomit, že každý další den hospitalizace stojí obrovské náklady, v USA se pohybuje v rozmezí 476-835 USD, v evropských zemích až po v průměru 4287 USD v USA.

S ohledem na tyto náklady je zásadní, aby sazby proplacení řádně pokryly náklady spojené s léčbou pacientů s infekcí CIED ve všech zúčastněných centrech. V Evropě jsou postupy proplácení obvykle založeny na skupinách spojených s diagnózou („diagnosis related groups“) a vykazují dưležitou variabilitu pro postupy zařízení, a pokud je tento tarif nedostatečný, může politika proplácení "zasahovat" do volby lékaře u nejsložitějších pacientů se značným rizikem suboptimální péče.

Posouzení zdravotnických technologií je specifickým nástrojem komplexního prístupu k této složité otázce, do něhož jsou zapojeny všechny zúčastněné strany. Velké národní a mezinárodní registry mají zásadní význam pro analýzu způsobu doporučení, výsledků extrakcí elektrod a výsledků, to celé s perspektivou optimalizace řetězce péče za účasti mnoha zúčastněných stran v organizačním systému „středisko a paprsky”, který by měl zaručovat odbornou péči, spojující účinnost s vhodným využitím zdrojů.

\section{Odlišná doporučení různých odborných společností}

Strategie pro prevenci a léčbu infekcí CIED se velmi liší a důkazy pro vedení praxe jsou omezené. Až dosud byly pokyny o tom, jak předcházet, diagnostikovat a léčit infekce CIED, zveřejněny pouze American Heart Association (2010) a britskými společnostmi British Society for Antimicrobial Chemotherapy, British Heart Rhythm Society, British Cardiovascular Society, British Heart Valve Society a British Society of Echocardiography (2015). Kromě toho v roce 2015 vydala Evropská kardiologická společnost a American Heart Association poky- 
Tabulka 14 - Minimální studijní proměnné pro vědecké studie a registry

Skupina proměnných

Datové pole

Hodnotová doména

Charakteristiky nemocnice

Referenční centrum pro extrakce elektrod

Ano/Ne

Demografické faktory

Počty implantací prístrojů

Počet za rok

Věk

Pohlaví

Užíaání intravenózních drog

Dosažené vzdělání

Základní klinické faktory

Komorbidity

Medikace

Specifické rizikové faktory

Charakteristiky CIED

Předchozí výkony

Chronické onemocnění ledvin

Diabetes mellitus

Srdeční selhání

Chlopenní náhrada

Nádorové onemocnění

HIV infekce

Perorální antikoagulancia

Kortikosteroidy

Imunosupresiva

Perkutánní katétry z různých indikací (infuze, kardiostimulátor, hemodialýza)

Typ CIED

Umístění kapsy generátoru pulsů

Typ elektrody

Datum implantace CIED

Celkový počet elektrod

Zaslepené elektrody

Elektrody na obou stranách hrudníku

Poslední procedura CIED

Datum stanovení diagnózy infekce (čas mezi poslední procedurou CIED a současnou epizodou infekce)

Zaslepené elektrody

Hospitalizace spojená se současnou epizodou infekce

Datum príijetí

Symptomy - horečka nebo hypotenze

Známky infekce kapsy

Známky systémové infekce

Septický šok

Diagnostické metody

Hemokultury

Nálezy z jícnové echokardiografie
Mikrobiální patogeny

Masa spojená s CIED, masa v pravé síni nebo pravé komoře

Vegetace trikuspidální chlopně

Vegetace v levém srdci
Datum narození

Pohlaví při narození

Ano/Ne

Nejvyšší ukončené vzdělání

Ano/Ne

Ano/Ne

Ano/Ne

Ano/Ne

Ano/Ne

Ano/Ne

Ano/Ne

Ano/Ne

Ano/Ne

Ano/Ne

Kardiostimulátor v režimu DDD, SSI

ICD VR

ICD DR

CRT-P

CRT-D

ICD - subkutánní

Bezelektrodový kardiostimulátor (LPM)

Pektorálně/abdominálně

Transvenózní/epikardiální/ subkutánní/hybridní

RRRR-MM-DD nebo jak je určeno

(Číslo)

Ano/Ne

Ano/Ne

Iniciální implantace/výměna generátoru/revize elektrody/upgrade

RRRR-MM-DD nebo jak je určeno

Žádná/transvenózní/epikardiální

RRRR-MM-DD

Ano/Ne

Ano/Ne

Ano/Ne

$\mathrm{Ano} / \mathrm{Ne}$ 
Tabulka 14 - Minimální studijní proměnné pro vědecké studie a registry

Skupina proměnných

Duke kritéria

Nálezy z $\left[{ }^{18} \mathrm{~F}\right] \mathrm{FDG}$ PET/CT

Konečná diagnóza

Léčba

Odstranění CIED

Reimplantace CIED

Výsledky

\section{Datové pole}

Potvrzená infekce spojená s CIED

Možná infekce spojená s CIED

Glykolytická aktivita spojená s CIED

Absence glykolytické aktivity

Časný poimplantační zánět incize

Nekomplikovaná infekce kapsy

Komplikovaná infekce kapsy generátoru

Infekce elektrody CIED

Infekční endokarditida spojená s CIED

Antibiotická léčba

Datum zahájení léčby antibiotiky

Empirická léčba antibiotiky

Cílená antibiotická léčba (podle výsledku hemokultur)

Délka antibiotické léčby (před odstraněním

CIED)

Délka antibiotické léčby (po odstranění CIED)

Komplikace antibiotické léčby

Datum odstranění pulsového generátoru

Datum odstranění elektrod

Způsob odstranění elektrod

Výsledek odstranění elektrod

Výsledek kultivace tkáně kapsy

Výsledek kultivace hrotu elektrody

Uzávěr rány

Datum reimplantace

Typ CIED

Umístění kapsy generátoru pulsů

Vstup elektrod

Datum propuštění

Klinický stav při propuštění

Potřeba rehospitalizace

Datum rehospitalizace

Rekurentní infekce

Úmrtí

Datum úmrtí
Hodnotová doména

\author{
RRRR-MM-DD \\ Ano/Ne \\ Druh antibiotik \\ Dávka/cesta aplikace \\ Ano/Ne \\ Druh antibiotik \\ Dny \\ Dny \\ Ano/Ne \\ Typ komplikace
}

RRRR-MM-DD

RRRR-MM-DD

Prostá trakce, locking stylet, jednoduchý mechanický extrakční sheath, rotační mechanický extrakční sheath, laserový sheath, užití extrakční smyčky přes tříslo, užití extrakční smyčky přes jugulární žílu, jiné nástroje, perkutánní aspirace vegetací, chirurgická extrakce bez mimotělního oběhu, chirurgická extrakce při mimotělním oběhu

Kompletní/nekompletní, závažné/menší komplikace

Ano/Ne

Hlavní nálezy

Ano/Ne

Hlavní nálezy

Primární uzávěr rány - drén, odložený uzávěr hojení rány s podtlakovou terapií

\section{RRRR-MM-DD}

Kardiostimulátor, ICD, CRT

Pektorálně/abdominálně

Transvenózní/epikardiální/hybridní/

bezelektrodový kardiostimulátor/S-ICD

\section{RRRR-MM-DD}

Vyřešená infekce/nevyřešená infekce/úmrtí

Ano/Ne

RRRR-MM-DD

Ano/Ne

Ano/Ne

RRRR-DD-MM 
Tabulka 14 - Minimální studijní proměnné pro vědecké studie a registry

\begin{tabular}{|c|c|c|}
\hline Skupina proměnných & Datové pole & Hodnotová doména \\
\hline & Příčina úmrtí & $\begin{array}{l}\text { Komplikace extrakce elektrod } \\
\text { Infekce CIED (sepse) } \\
\text { Dysfunkce CIED } \\
\text { Refrakterní srdeční selhání } \\
\text { Úmrtí z kardiálních příčin - jiné } \\
\text { Nekardiální př́čina } \\
\text { Nezjištěná příčina } \\
\text { Ostatní }\end{array}$ \\
\hline
\end{tabular}

CIED - srdeční implantabilní elektronické zařízení; CRT - srdeční resynchronizační léčba; CRT-D - resynchronizační terapie s defibrilátorem; CRT-P - biventrikulární kardiostimulátor; $\left[{ }^{18} \mathrm{~F}\right] \mathrm{FDG}$ PET/CT - pozitronová emisní tomografie/výpočetní tomografie s podáním fluorodeoxyglukózy značené fluorem-18; ICD - implantabilní kardioverter-defibrilátor.

ny pro léčbu infekční endokarditidy a společnost Heart Rhythm Society (HRS) nedávno vydala konsenzuální prohlášení o zacházení a extrakci elektrod kardiovaskulárních implantabilních zařízení, které poskytuje praktické klinické vedení v široké oblasti managementu elektrod, včetně případů infekce elektrod. Souhrn hlavních odlišných doporučení v těchto pěti guidelines je uveden v tabulce 13 .

\section{Obecné definice a minimální požadavky na proměnné ve vědeckých studiích a registrech}

Registry srdečních zařízení byly použity v mnoha centrech po celém světě; standardní definice datového souboru pro pacienty s infekcí CIED však zůstává nedostupná. Byl publikován dokument věnovaný tomuto tématu ohledně extrakcí elektrod. Přijetí standardizovaných datových prvků a standardní terminologie je pravděpodobně klíčem k usnadnění výměny dat mezi studiemi a $\mathrm{k}$ podpoře vzájemné operability mezi rưznými systémy elektronických zdravotních záznamů. Kromě toho standardizované měření výsledků zřejmě otevře nové možnosti pro srovnání provádění výkonu celosvětově, poskytující lékařské komunitě reálné důkazy ke zlepšení zdravotní péče o pacienty. Minimální datový soubor proměnných je podrobně uveden v tabulce 14, která slouží jako vodítko při navrhování registrů infekce CIED (tabulky 12-14), a to jak ve vědeckém, tak v klinickém prostředí. Nutnost zachycení individuálních parametrů bude záviset na účelu studie/ registru.

\section{Mezery v důkazech}

1. Dlouhodobá úmrtnost u pacientů s infekcí CIED je až 2,5krát vyšší než úmrtnost neinfikovaných pacientů. Není jasné, zda souvisí se samotnou infekcí CIED, špatnými prognostickými faktory, souvisejícími přímo s pacientem nebo neadekvátní péčí.

2. Optimální načasování revize (např. pro repozici elektrody) za účelem snížení rizika infekce je nejasné.

3. Ochranná role adhezivních chirurgických antibiotik nebo jiných roušek pro prevenci infekcí je nejasná.

4. Chybí optimální strategie stratifikace nebo kalkulátor rizika k minimalizaci možné infekce CIED.

5. Role $\left[{ }^{18} \mathrm{~F}\right]$ FDG PET/CT a scintigrafie se značenými leukocyty při diagnostice a sledování okultních a manifestních infekcí CIED vykazuje čím dál větší klinickou užitečnost, ale je třeba ji ještě dále objasnit.

6. Trvání pooperační antibiotické terapie po úplném odstranění systému CIED z infekčních dưvodů není jasné.

7. Optimální strategie záchrany u těžce nemocných nebo křehkých pacientů s infekcemi CIED, u nichž je úplné odstranění systému považováno za př́liš vysoké riziko, není známa.

8. Správné načasování reimplantace po infekcích CIED není jasné.

9. U pacientů závislých na stimulaci s infekcí CIED je strategie po extrakci elektrody nejasná. Po přechodné fázi externí stimulace aktivně fixovanou elektrodou se jako trvalé rešení nabízí implantace zařízení na kontralaterální stranu, umístění elektrody epikardiálně nebo leadless pacemaker.

10. V př́padě infekce kapsy s kontralaterální zaslepenou elektrodu bez systémové infekce není jasné, zda má být elektroda extrahována či nikoli. 


\section{Shrnutí nových zpráv a výzva $\mathrm{k}$ předložení vědeckých důkazů}

1. V prospektivních studiích se zdá, že počet infekcí elektronických implantabilních srdečních zařízení je nižší $(1,2 \%)$ než v retrospektivních registrech $(3,4 \%)$, což může souviset s důslednějším dodržováním širokých preventivních opatření při účasti v prospektivních studiích. Posouzení skutečné míry infekce v praxi je naléhavě nutné, aby bylo možné přesněji definovat přínos různých strukturovaných preventivních programů, zacílit na modifikovatelné rizikové faktory a vyvinout schémata stratifikace rizika pro implantaci a reimplantaci zařízení.

2. Ačkoli bylo vydáno několik pokynů a doporučení různých lékařských společností pro léčbu infekcí CIED, celosvětový průzkum EHRA týkající se klinické praxe při léčbě infekcí CIED odhalil významné regionální rozdíly v současné praxi, neúplné dodržování doporučení a nedostatek hlubokých znalostí o zvládání infekcí CIED, což umocňuje potřebu širších a uživatelsky přívětivějších mezinárodních pokynů a implementačních programů.

3. Extrakce zařízení by měla být načasována co nejdříve po stanovení diagnózy infekce CIED, protože pokud je provedena v průběhu prvních tři dnů hospitalizace, má to za následek významně nižší nemocniční úmrtnost a kratší hospitalizaci. Je to také zásluhou lepších diagnostických nástrojů.

4. Nejdůležitějšími rizikovými procedurálními faktory pro infekce související se zařízením jsou hematom kapsy, dlouhé trvání výkonu a revize pro přemístění elektrody. Strategie, které těmto rizikưm předcházejí, by měly být lépe definovány a prováděny důrazněji.

5. Antibakteriální obálka snižuje počet infekcí CIED u pacientů s vysokým rizikem infekce související se zařízením. Další analýza odvozená z reálné praxe poskytne více informací o její účinnosti a výkonu v méně selektovaném nastavení. Schéma stratifikace rizika optimalizuje využití této techniky.

6. Pooperační podávání antibiotika se obecně nedoporučuje.

7. Aspirace jehlou a chirurgický débridement v případě infekce kapsy nejsou doporučovány jako možnost vyhnout se extrakci elektrod. Jsou vyžadovány lepší diagnostické nástroje.

8. $\left[{ }^{18} \mathrm{~F}\right]$ FDG PET/CT sken, scintigrafie značenými leukocyty nebo CT s kontrastní látkou se doporučují při podezření na infekční endokarditidu spojenou s CIED, při pozitivní hemokultuře a negativní echokardiografii.

9. V případě bakteriemie způsobené $S$. aureus u pacienta s CIED je doporučeno provést [ ${ }^{18}$ F]FDG PET/CT.

10. Promyšlené velké národní nebo mezinárodní povinné uživatelsky přivětivé registry implantací zařízení a jejich komplikací s pravidelným monitorováním a vnitrostátními požadavky minimálních ročních počtů výkonu, operatérů a center mohou být konečným přístupem ke snížení infekcí souvisejících se zařízením.

\section{Literatura*}

1. Blomström-Lundqvist C, Traykov V, Erba PA, et al. European Heart Rhythm Association (EHRA) international consensus document on how to prevent, diagnose, and treat cardiac implantable electronic device infections - endorsed by the Heart Rhythm Society (HRS), the Asia Pacific Heart Rhythm Society (APHRS), the Latin American Heart Rhythm Society (LAHRS), International Society for Cardiovascular Infectious Diseases (ISCVID) and the European Society of Clinical Microbiology and Infectious Diseases (ESCMID) in collaboration with the European Association for Cardio-Thoracic Surgery (EACTS). Europace 2020;22:515-549.

* Všechny další odkazy Ize nalézt v původním fulltextovém dokumentu EHRA 